\title{
RECORDS OF PYCNOGONIDA FROM SHALLOW WATERS OF JAPAN
}

\author{
$\operatorname{AUTHOR}(S)$ :
}

Utinomi, Huzio

\section{CITATION:}

Utinomi, Huzio. RECORDS OF PYCNOGONIDA FROM SHALLOW WATERS OF JAPAN. PUBLICATIONS OF THE SETO MARINE BIOLOGICAL LABORATORY 1971, 18(5): 317-347

\section{ISSUE DATE:}

1971-01-30

URL:

http://hdl.handle.net/2433/175643

RIGHT: 


\title{
RECORDS OF PYCNOGONIDA FROM SHALLOW WATERS OF JAPAN ${ }^{132}$
}

\author{
Huzio UTINOMI
}

Seto Marine Biological Laboratory, Sirahama

About thirty five years ago, Onshima (1936) compiled all species of the Pycnogonida so far recorded from Japanese and adjacent waters irrespective of their occurring depths and enumerated 34 species and 3 varieties, and also 4 indeterminable forms (totalling 41).

Dr. Ohshima's interest in the Pycnogonida, against his first intention as noted in that paper, actually extended mainly to the other works on their ecology, life history and malformation, etc. until his retirement. Since then, however, the taxonomic or faunistic work on the group from western Pacific waters including Japan has been succeeded thoroughly, fortunately enough, by HedgPeth, Stock and U'tinomi.

In recent years after my papers $(1955 \mathrm{a} \sim 1962)$ appeared, fairly extensive collections of littoral pycnogonids have been accumulated at my hand by the cordial co-operation of many persons and institutions year by year. Most of the specimens belonging to ordinary species have been returned to the collectors or institutions after the identification, but some of them have retained for future reference are now deposited in the museum of the Seto Marine Biological Laboratory.

The aim of this paper is to enumerate all the pycnogonids found in shallow waters on the continental shelf around the main Islands of Japan proper, based on the present collections and the existing records from available literature up to the present time.

This review is thus confined to the pycnogonids occurring in relatively shallow waters, the main deep-water dwellers being discarded. Likewise, the arctic boreal forms mainly recorded from the adjacent eastern coasts of the Soviet territory are largely excluded. Any unnamed species are also discarded from the following list.

The order of families is the conventional one generally adopted merely to facilitate reference to older records of occurrence and does not purport to be a phylogenetic sequence.

On this occasion, Japanese names are newly proposed for some of the species

1) This paper is dedicated to Dr. Hiroshi Ohshima, M.J.A., the famous grand old man of Japanese zoologists who made the first and thorough observations on Japanese Pycnogonida, and inspired me to the taxonomic work with the Pycnogonida.

2) Contributions from the Seto Marine Biological Laboratory, No. 535.

Publ. Seto Mar. Biol. Lab., XVIII (5), 317-347, 1971. (Article 23) 
listed below.

The place names in Japanese terms appeared in the text are romanized herein following the HEPBURN system.

For the details of pycnogonid samplings carried out during the benthos survey in the Chijiwa Bay and around the Amakusa Islands, western Kyushu, a separate paper will be prepared.

Depositories of some specimens specially notified are abbreviated as follows:

Biological Laboratory of the Imperial Household, Tokyo-B.L.I.H.

Mukaishima Marine Biological Station of Hiroshima University, Mukaishima, Hiroshima-ken-M.M.B.S.

Seto Marine Biological Laboratory of Kyoto University, Shirahama, Wakayamaken-S.M.B.L.

\section{Acknowledgments}

I am very much obliged to Drs. Hiroshi Ohshima, Joel W. Hedgpeth and Jan H. STock for their inspiration and friendship led me to the Pycnogonid research. Moreover I am highly indebted to many persons and institutions mentioned under the subject of materials in each of the species listed. To them I offer my sincere gratitude for their kind co-operation in collecting samples without which this work might have been impossible.

\section{Check-list of Pycnogonida Found in Shallow-waters of Japan}

\section{Family NYMPHONIDAE WILSON}

Genus Nymphon J. C. FABRICIUS, 1794

1. Nymphon grossipes (O. FABRICIUS?) KR申YER キタユメムシ(新)

Nymphon grossipes, Hedgpeth, 1949: 247 (syn. et lit.); Utinomi, 1955a: 4, fig. 1; Utinomi, 1959: 198. N. mixtum KR $\phi$ YeR, OHSHIMA, 1936: 862.

\section{New materical:}

10. Off Tassha, Sado Is., 150 fms. 10-XII-68, T. Kitami coll.

Previous records: Off Shimoda, Sagami Bay, 247 m (Uтімомi, 1955a); Sagami Bay, $8 \mathrm{fms}$ (Uтіломi, 1959).

Distribution: Circumpolar, widespread throughout North Atlantic to Siberian coasts.

\section{Nymphon longitarse KRфYER ナガスネユメムシ(大島)}

Nymphon longitarse KR $\phi_{\mathrm{YER}}$, Losina-Losinsky, 1933: 67; OHSHIMA \& Kishida, 1947: 1006, fig. 2855; Hedgpeth, 1949: 247 (syn. et lit.); Losina-Losinsky, 1961: 65.

Previous records: Northwest of Hokkaido, 390-428 $\mathrm{m}$ and southwest of Hok- 
kaido, 52-75 m (Hedgreth, 1949); off Osyoro, west coast of Hokkaido (Utinomi, 1954:2, after Dr. S. MotodA's information).

New material:

1 specimen, VIII-67, K. Konno coll. (Uahida et al., 1970:10). Off Fukaura, west coast of Aomoriken.

Distribution: Circumpolar in boreal arctic waters, mainly in shallow depths. This species appears to be common in the northeastern part of the Japan Sea as well.

\section{Nymphon striatum LoSINA-LOSINSKY ツノユメムシ(新)}

Nymphon striatum Losina-Losinsky, 1929: 538, fig. 1; Losina-Losinsky, 1933: 64, fig. 13; Utinomi, 1954: 2, fig. 1; Nesis, 1967: 248.

Previous records: Daikoku-jima:, mouth of Akkeshi Bay, Hokkaido (UTinomi, 1954); northwestern part of the Japan Sea north to the Tatary Straits, in 0-103 m (Losina-Losinsky, 1933, 1961).

\section{Nymphon braschnikowi SCHIMKEWITSCH ブラシュニコフュメムシ(新)}

Nymphon braschnikowi Sсhмmеwiтsch, 1906: 248; Sqhiмкеwiтsch, 1930: 507, figs. 154-160, pl. IX, figs. 1-2; Ohshima, 1936: 863; Неdgғeтh, 1949: 250, fig. 2la-c; Utinomi, 1955a: 6, fig. 2; LOSINA-LOSINSKY, $1961: 62$.

Previous records: Off the southern coast of Hokkaido, 52 to $175 \mathrm{fms}$ or perhaps $349 \mathrm{fms}$ (Hedgretr, 1949); off Miyako, Iwate-ken, $494 \mathrm{~m}$ (Utinomr, 1955a).

Distribution: Characteristic to the Okhotsk Sea, where it occurs mainly in shallow waters. Its range extends far south of latitude $40^{\circ} \mathrm{N}$, but in northern Japan the occurrence descends to deeper basin, as shown by the collecting records of the "Albatross" and "Soyo-maru" Expeditions.

\section{Nymphon hodgsoni SCHIMKEWITSCH ホジソンユメムシ(新)}

Nymphon hodgsoni Schimkewrtsch, 1913: 2444, pl. 3a, figs. 15-25; Sснімkewirsah, 1930: 512, figs. 161-166, pl. 10; Losina-Losinsky, 1933: 71; Ohshima, 1936: 863; Hedgreth, 1949: 250 , fig. 21d-g; Losina-Losinsky, 1961: 63.

New material:

10 (S.M.B.L., Pyc. 62). Off Utoro, Shiretoko Peninsula, Hokkaido, 600 m. 17-VII-68, T. Honma coll.

Distribution: Japan Sea, Tatary Straits, Okhotsk Sea and southern Kuriles. Its bathymetrical range is $99-110 \mathrm{~m}$ in Tatary Straits (after SchrmkewrTsch), 75-100 fms in the east of Sakhalin (after HEDGPETH), 72-210 $\mathrm{m}$ in the northwestern part of the Japan SEA (after Losina-Losinsky) and $42-414 \mathrm{~m}$ in the Okhotsk Sea (after LOSINA-LOSINSKY). 


\section{Nymphon japonicum ORTMANN イトュメムシ(岸田)}

Nymphon japonicum Ortmann, 1891: 158, pl. 24, fig. 1; Loman, 1911: 8 (part.); Ohshima, 1936; 862; HedGpeth, 1949: 249 (emended); Utinomi, 1951: 159; Sтоск, 1954: 19, fig. 6a-c; Utinomi, 1955a: 5; Utinom, 1959: 199; Uтпомі, 1962: 92; Utinomi, 1965: 334, fig. 13.

Nere material:

10. Off Tassha, Sado Is., Niigata-ken, 150 fms. 10-XII-68, T. KiтAmr coll.

$1{ }^{\hat{\alpha}}$ (B.L.I.H., Pyc. 81). $4 \mathrm{~km}$ WSW of Jyoga-shima, Sagami Bay, $200 \mathrm{~m}$. 10-II-63.

$1 \hat{\alpha}$ (S.M.B.L., Pyc. 63). Mihara Bay, Hiroshima-ken, Seto Inland Sea, unknown depth. VII XI56, K. Nagata coll.

4수으, 2우우. Chijiwa Bay, Nagasaki-ken, 61 m. 20-VIII-63, 16-X-63, 20-XI-63, 16-IX-63, T. KIKUCHI \& A. TAKI coll.

Distribution: Apparently endemic in Japanese warm waters. Its bathymetrical range is perhaps wide, although previous records are given as $36 \mathrm{~m}$ to $432 \mathrm{~m}$ in depth.

\section{Nymphon ortmanni HELFER オルトマンユメムシ(新)}

Nymphon japonicum, LoMAN, 1911: 8 (part.)

N. ortmanni Helfer, 1938: 164, fig. 1; Sтоск, 1953a: 34, fig. 1; Sтоск, 1954: 20, fig. 6d-e; Utinom, 1955a: 10, fig. 5; Utinomi, 1962: 92.

New material:

$2 \sigma^{3}$ (B.L.I.H., Pyc. 82). $6.5 \mathrm{~km}$ WSW of Jyoga-shima, Sagami Bay, $450 \mathrm{~m} .13-$ VII-63.

Previous records: Sagami Bay, 80-120 fms (Loman, Helfer, Utinomi); Tsugaru Straits, 108 m (Uтіломi, 1955 a); off Unisapi (? Malay Arch.), 200 fms (Sтоск, 1954).

\section{Nymphon elongatum HiLTON ヒルトンュメムシ(新)}

Nymphon elongatum HiLton, 1942a: 5 (diagnosis); Hedgreth, 1949: 251, figs. 22 \& 34f; STock, 1954: 17, fig. 5 .

Previous records: Toyama Bay (Albatross Sta. 4822), $130 \mathrm{fms}$ (Hedgpeth); 15 miles W of Nagasaki $\left(32^{\circ} 40^{\prime} \mathrm{N}, 129^{\circ} 34^{\prime} \mathrm{E}\right.$ ), $60 \mathrm{fms}$ (Sтоск). The type locality is, however, very remote from Japan proper, being SE of Kamtchatka Peninsula (Albatross

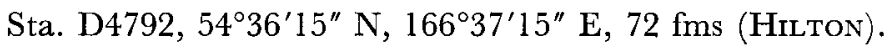

\section{Nymphon kodanii HedGPETH コダニユメムシ(新)}

Nymphon kodanii Hedgreth, 1949: 252, fig. 23; Stock, 1954: 21, fig. 6f; Utinomi, 1955a: 7, fig. 3; Uтімомi, 1962: 92.

Nere material:

$1^{\star}$ (B.L.I.H., Pyc. 75). SW of Jyoga-shima, Sagami Bay, 230-280 m. 12-VII-62.

Distribution: Apparently confined to Japan, in moderately deep waters, from the 
northeastern part of the Japan Sea to the west of Kyushu, with a wide bathymetrical range ( 75 to $649 \mathrm{fms}$ ). In Sagami Bay, it was obtained from the depth of 190-280 m.

\section{Nymphon micropedes HEDGPETH ニセイトユメムシ(内海)}

Nymphon micropedes HedGPETh, 1949: 254, fig. 24; Utinomi, 1955a: 9, fig. 4; Utinomi, 1965: 334, fig. 14.

N. japonicum, Kishida, 1927: 990, fig. 1907; Ohshima \& Kishida, 1917: 1007, fig. 2856 (nec Ortmans).

Distribution: Originally recorded from the Albatross Sta. 5080 (south of Suruga Bay, $505 \mathrm{fms}$ ). Later I recorded from the Soyo-maru Stations 645 and 647 (west of Tsugaru Straits, 85-113 m) (UTinomi, 1955a).

\section{Nymphon stocki UTINOMI ストックユメムシ(新)}

Nymphon stocki Utinomi, 1955a: 10, figs. 6-7.

Previous record: Soyo-maru Sta. 572, north of Noto Peninsula, Japan Sea, 132m.

\section{Nymphon soyoi UTINOMI ソウヨウユメムシ(新)}

Nymphon soyoi Utinomi, 1955a: 13, fig. 8.

Previous record: Soyo-maru Sta. 558, west of Noto Peninsula, Japan Sea, $188 \mathrm{~m}$.

\section{Nymphon falcatum UTINOMI カマツメユメムシ(新)}

Nymphon falcatum Utinomi, 1955a: 15, fig. 9; Sтоск, 1956: 94, fig. 15.

Previous records: Soyo-maru Sta. 315, off Mimitsu, Miyazaki-ken, eastern Kyushu,

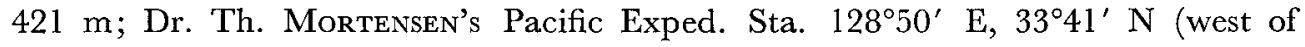
Goto Islands, western Kyushu, $75 \mathrm{fms}$ ).

\section{Nymphon giraffa LOMAN ジラフユメムシ(新)}

Nymphon giraffa Loman, 1908: 39, pl. VI, figs. 74-82; Utinomi, 1962: 92, figs. 1-2.

Previous records: Originally recorded from the Siboga Sta. 81, Makassar Strait, Indonesia, $34 \mathrm{~m}$. Later it was found in Sagami Bay, 65-70 m.

\section{Family CALLIPALLENIDAE HILTON (=PALLENIDAE WILSON) \\ Genus Propallene SchIMkewitsch, 1909}

15. Propallene longiceps (BöHM) ツメナガウミグモ(大島)

Pallene longiceps Böhm, 1879b: 59; Ortmann, 1890: 165, pl. 24, fig. 7; Fukui, 1918: 99; Ohshima, $1933 \mathrm{c}: 212$, figs. $1-7$. 
Propallene longiceps, Sснтмкеwitsah, 1930: 282 (1929, pl. 41, fig. 3); Ohsнima, 1936: 863; Sтоск, 1954: 31, fig. 12a-b; Uтімомr, 1959: 199; Uтілом, 1962: 96; Uтіломі, 1965: 334, fig. 15.

New material:

$150 \sigma^{a}, 2 q q$, many juveniles. Nonai Inlet, Aomori Bay, Zostera belt, 2-6 m. 5 6-IX-60, H. SANDo coll.

(SANDo, 1964: 30).

7우우. Sendai Bay, Miyagi-ken, 10-30 m. 4-VII-67, G. Yамамото coll.

42 $千$ ㅇ. Nabeta Bay, Shimoda, Izu Penin., 30-40 m. V-61, S. Konuma \& K. Sekigughi coll.

12우우. Misaki, Sagami Bay. 17-VI-62, S. Gamo coll.

$13 \delta^{\prime}+$ (S.M.B.L., Pyc. 65). Tanabe Bay, in surface tow-nets. X-56, I. YAMAzI coll.

Many off (S.M.B.L., Pyc. 9). Kasaoka Bay, Okayama-ken, Zostera belt. XII-52, Sh. Fuse coll.

1亏. Kurushima Strait, Ehime-ken. VIII-56, K. Morikawa coll.

o웅 (M.M.B.L., No. 58-3). Mukaishima, Hiroshima-ken, in surface tow-nets. 15-XI-62, Iw. TAKI coll. (INABA, 1963: 206).

10. Tomioka Bay, in tow-nets. 23-IV-63, T. KIKUaHi coll.

10, 6우. Chijiwa Bay, Nagasaki-ken, 16-40 m. 12 17-VI-63, T. Kıкuchr \& A. TAкI coll.

Distribution: Prevalent and abundant in shallow waters around Japan proper, especially in eelgrass belt of inner bays. Often taken in large numbers with pelagic tows at night.

\section{Genus Callipallene FLYNN, 1929 \\ (pro Pallene Johnston, 1837)}

\section{Callipallene dubiosa HEDGPETH カニノテゥミグモ(内海)}

Callipallene dubiosa Hedg peth, 1949: 275, fig. 35; Stock, 1954: 41, fig. 17; Stock, 1957a: 88; Utinom, 1965a: 335, fig. 16 .

Previous records: Hakodate (Hokkaido, Tsugaru Straits), shore...type locality (Hedgreth); off Amoy, 8-25 fms; Singapore, low-tide and Paumben, India, 1-5 fms (STock); Zanzibar, Bawi Is. (East Africa)(STock).

Remarks: Judging from the occurring records cited above, this species found at Hakodate, Hokkaido can be considered a tropical or subtropical immigrant, instead of a true boreal species as originally considered.

\section{Callipallene phantoma amaxana (OHSHIMA) ナガクビカニノテウミグモ(新)}

Pallene amaxana Oнsнiма, 1933c: 217, figs. 8-12; Oнsнiмa, 1936: 863.

Callipallene brevirostris, Oнshima, 1942a: 257, figs. 1-3; Oнsнima, 1943b: 371, figs. 1-2 (nec Johnston, 1873).

?Pallene producta, OHshima, 1933c: 96 (nec G.O. SARs, 1888).

Callipallene phantoma, UTiNomi, 1962: 95, fig. 3.

Callipallene phantoma amaxana, STock, 1968: 37, fig. 14a-d.

Previous records: Misaki of Sagami Bay, Sasebo Bay and Tomioka Bay, taken by night tows (Ohshima); off Jyogashima, Sagami Bay, 100-160 m (Utinomi); Malacca Straits, $77 \mathrm{~m}$ (STOck). 
New material:

$2 \delta^{A}$ (S.M.B.L., Pyc. 78). Fukashima in Kamae Bay, Oita-ken, Bungo Strait, on algae, $4 \mathrm{~m}$ deep. 18VII-65, T. TоKIOKA coll.

18. Callipallene conirostris STOCK ホソクチカニノテゥミグモ(新)

Callipallene conirostris STock, 1954: 39, figs. 16 and 20f-g.

Previous record: Sagami Bay, 80-120 fms.

\section{Genus Parapallene Carpenter, 1892}

19. Parapallene nierstraszi LOMAN チビオウマヅラウミグモ(新)

Parapallene nierstraszi Loman, 1908: 44, pl. IX, figs. 122-127; FlynN, 1928: 18; Calman, 1938: 158; fig. 7; Barnard, 1954: 113; Stock, 1954: 52, fig. 24f; Utinomi, 1955a: 18, fig. 10.

Previous records: South Africa, 25 fms (FlynN, Barnard); southeast Asia, low tide to $112 \mathrm{~m}$ (Loman, Calman, Stock); Tsushima Straits, Japan, $112 \mathrm{~m}$ (Utrinomi). New material:

1 ovig. ơ (S.M.B.L., Pyc. 81). Nishihama, west coast of Tomioka, Amakusa Is. 6-X-56, T. HABE coll.

5ồ. Chijiwa Bay, north of Tomioka, Nagasaki-ken. 28-VI-63, T. Kikuchi coll.

\section{Genus Pseudopallene WILSON, 1878}

\section{Pseudopallene zamboangae STOCK クチヒゲウミグモ(新)}

Pseudopallene zamboangae Sтоск, 1953b: 297, figs. 12b-c, 13; Sтоск, 1954: 61, fig. 27d-f.

Previous records: Sulu Sea, near Zamboanga, 9 fms (Sтоск, 1953b); off Jolo, 20-50 fms, Java Sea, 35 m (Sтоск, 1954).

New Material:

1 (o (S.M.B.L., Pyc. 87). Chijiwa Bay, Nagasaki-ken (Benthos survey sta. 6158, 65 m). 26-VI-61, T.

HABE coll.

\section{Genus Pallenopsis WILson, 1881}

21. Pallenopsis tydemani LoMAN オナガカギノテウミグモ(新)

Pallenopsis tydemani Loman, 1908: 65, pl. 10, figs. 139-145; HedGPeth, 1949: 277, fig. 36i-j; Utinomi, 1951: 160.

Previous records: Malay Archipelago (Siboga stations 45 and 314), $794 \mathbf{m}$ and $964 \mathrm{~m}$ (Loman); west of Koshiki Is., Kyushu (Albatross station 4908), $434 \mathrm{fms}$ (HedgPETH); off Minabe, SW of Kii Peninsula, 100-200 m (Utinomi). 


\section{Pallenopsis virgata LOMAN カギノテゥミグモ(内海)}

Pallenopsis virgatus Loman, 1908: 69, pl. 9, figs. 135-136; Hedgreth, 1949: 277, fig. 36g-h; Utinomi, 1951: 160 .

P. virgata, Utinomi 1959: 200; Utinomi, 1965: 335, fig. 17.

Previous records: North of Sumbawa, Malay Arch. (Siboga Sta. 310), 34-37 m (Loman); southwest of Omae-saki (Albatross Sta. 3730), 34-37 fms (HedGeth); off Yuzaki, 25-35 m (Utrnomi, 1951); Sagami Bay, 30-32 m (Uтіnomi, 1959).

New material:

19 (S.M.B.L., Pyc. 67). Akaiwasaki, Tomioka, Amakusa Is., 20 m. VII-57, T. HAbE coll.

$30^{\star}$. Chijiwa Bay, Nagasaki-ken (Benthos survey sta. 6306), $82 \mathrm{~m}$. 29-VII-64, T. KIkUchI and A. TAKI coll.

$1 ð$. North of Unoze, Amakusa Is. (Benthos survey sta. 6145), 45 m. 14-IV-64, T. KIKUaHi and A. TAKI coll.

16. Chijiwa Bay, Nagasaki-ken (Benthos survey sta. 6313), $66 \mathrm{~m}$. 11-III-64, T. KIkUGHI and A. TAKI coll.

Distribution: Widespread in Malay Archipelago and southern Japan, in shallow depths.

\section{Pallenopsis sibogae LoMAN カザリゲカギノテウミグモ(新)}

Pallenopsis plumipes Loman (nec Meinert, 1899), 1908: 66, pl. XII, figs. 160-164.

P. sibogae Loman, 1911: 14 (renamed); Sтоск, 1954: 63, fig. 30h-i; Utinom, 1955a: 19, fig. 11 ; Utinomi, 1959: 199; Uтіломі, 1962: 96.

Previous records: Kwandang Bay, North Celebes (Siboga Sta. 117), 80 m (Loman); Jolo, Philippines, 20-30 fms (Stock) ; Suruga Bay (Soyo-maru Sta. 278), 79 m (Utinomi, 1955a); Sagami Bay, 80-160 m (UTrNomi, 1959, 1962); west of Kyushu, $90 \mathrm{fms}$ (Sтоск).

\section{Pallenopsis temperans STOCK クビレカギノテウミグモ(新)}

Pallenopsis temperans Sтоск, 1953b: 291, fig. 10; Sтоск, 1954: 63, fig. 30g; Sтоск, 1968: 47.

Previous records: Jolo, Philippines (Albatross Sta. 5547), $155 \mathrm{fms}$; Korea Straits, 56 fms (Sтоск, 1954); Fanning Is., Central Pacific, 0.5 m (Sтоск, 1968).

\section{Pallenopsis hoeki (MIERS) ミナミカギノテゥミグモ(新)}

Phoxichilidium hoekii Mrers, 1884: 324, pl. 35, fig. B; Loman, 1908: 70.

Pallenopsis (Rigona) rigens Loman, 1908: 68, pl. IX, figs. 128-133.

Pallenopsis hoeki, CARPenter, 1893: 23, pl. II, fig. 11; FlynN, 1929: 257; Stock, 1953b: 288.

Previous records: Dundas Straits, $17 \mathrm{fms}$, Thursday Is., 4-5 fms (Mrers); Prince of 
Wales Channel, 7 fms (Loman); Jedan Is., 13 m (Garpenter); SW of Wales Channel, $7 \mathrm{fms}$ (Loman); Jedan Is., $13 \mathrm{~m}$ (Carpenter); SW of Mindanao Is. (Albatross Sta. 5595), 7 fms.

New material:

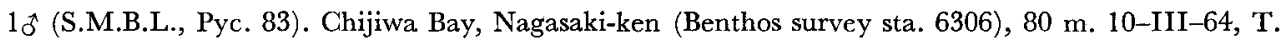
KIKUGHI and A. TAKI coll.

$1{ }^{\dagger}$ (S.M.B.L., Pyc. 84). Chijiwa Bay, Nagasaki-ken (Benthos survey sta. 6136), 16 m. 27-VIII-63,

T. KIKUGH and A. TAKI coll.

Distribution: Fairly common in Malayan shallow waters. This records thus extend its range north to Kyushu, southern Japan.

Genus Decachela Hilton, 1939

26. Decachela discata HILTON ゼニガタウミグモ(新)

Decachela discata Hilton, 1939: 34; Hilton, 1942e: 70; Hedgreth, 1949: 280, fig. 37.

Previous records: Pacific Grove, California (Hrtton); off Shakotanzaki, west coast of Hokkaido (Albatross Sta. 4987), $59 \mathrm{fms}$ (Hedgreth).

Distribution: This curious species is an amphi-Pacific boreal form, unknown from Honshu Island southward. Another spinous ally, D. dogieli was recently described from the northernmost end of Sakhalin Island, as settled on Pteraster (LosinaLosINSKY, 1961: 88, fig. 16).

\section{Family PHOXICHILIDIIDAE G. O. SARS Genus Phoxichilidium Milne Edwards, 1840}

27. Phoxichilidium ungellatum HEDGPETH ホソウミグモ(内海)

Phoxichilidium ungellatum Hedgreth, 1949: 281, fig. 38; Sтоск, 1954: 71; Uтіnomi, 1955a: 22, fig. 12.

New material:

Juveniles (S.M.B.L., Pyc. 17). Onagawa Bay, Miyagi-ken, in plankton tows of 0-5 m haul. 1950. I. YAMAZI coll.

Distribution: Prevalent in warm water around Main Islands of Japan, in the route of the Kuroshio and Tsushima Currents. Its bathymetrical range is very wide, according to the Albatross records, being 82-100 fms.

\section{Genus Anoplodactylus WiLson, 1878}

28. Anoplodactylus gestiens (ORTMANN) ソコウミグモ(内海)

Phoxichilidium gestiens Ortmann, 1891: 166, pl. 24, fig. 8a-d; Shishido, 1899: 200.

Anoplodactylus gestiens, Loman, 1911: 13; Fukui, 1918: 98; Ohshima, 1933c: 219; Ohshima, 1936: 864;

Hedqpeth, 1949: 284, fig. 40a-d; Sтоск, 1954: 71, fig. 31a-b; Utinomi, 1965: 335, fig. 19. 
New material:

Many $\delta ̛$ (S.M.B.L., Pyc. 72). Kugurizaka, Nonai Inlet, Aomori Bay, Zostera belt, 2-6 m. 23 24-

VIII, 5 6-IX-60, H. SANdo coll. (SANDo, 1964: 30).

$1{ }^{\star}$ (B.L.I.H., Pyc. 90). 4 km WSW of Jyogashima, Sagami Bay, 120-300 m. 28-VII-64.

1 ( (B.L.I.H., Pyc. 91). $2.5 \mathrm{~km}$ WNW of Jyogashima, Sagami Bay, 65-75 m. 13-II-65.

25우우 (S.M.B.L., Pyc. 63). Mihara Bay, Hiroshima-ken, Zostera-belt, 0-3 m. II-56-III-57, K. NAGA tA coll.

$1{ }^{\star}$ (S.M.B.L., Pyc. 60). Taken from the stomach contents of a bottom fish Synchiropus altivelis (T. \& S.).

Owase, Kumanonada, SE of Kii Penin. 12-XI-52, M. Akasaki coll.

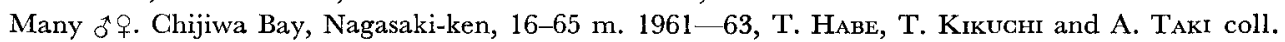

Distribution: Although previous records were mostly from moderate depths (e. g. 150-180 m down to $200 \mathrm{fms}$ in Sagami Bay, according to Loman, 31-68 fms in Suruga Bay, according to Hedgpeth, 80-120 fms in Sagami Bay, according to STOCK and $65 \mathrm{~m}$ in Sagami Bay according to UTINomi), most of the specimens newly examined have been collected from much shallower depths near the low tide, as in the case of Propallene longiceps BöнM).

\section{Anoplodactylus pycnosoma (HELFER) ツマリソコウミグモ(新)}

Peritrachia pycnosoma Helfer, 1938: 176, fig. 7.

Halosoma pycnosoma, MARcus, 1940: 45.

Anoplodactylus pycnosoma, Sтоск, 1953a: 41, fig. 5a-f; Sтоск, 1954: 75, fig. 33.

Previous records: Kobe (Helfer) and Misaki (Stock, 1954).

\section{Anoplodactylus hokkaidoensis (UTINOMI) エゾソコウミグモ(新)}

Phoxichilidium hokkaidoense Uтімомг, 1954: 4, fig. 2, pl. I fig. 1; Uтімомт, 1965 : 335, fig. 18.

Previous records: Muroran and Akkeshi, southern coast of Hokkaido, on hydroids.

\section{Anoplodactylus versluysi LoMAN トンガリソコウミグモ(内海)}

Anoplodactylus versluysi Loman, 1908: 73, pl. 3, figs. 33-39; Sтоck, 1954: 84, figs. 38a \& 39; Uтіnомi, 1959: 200; Sтоск, 1965: 29, fig. 46.

Previous records: Malay Archipelago, 34 m, 73 m and 120-400 m (Loman, 1908); Singapore, low tide (Sтоск, 1954); Madagascar, 50 m (Stock, 1965); Sagami Bay, 66-90 m (Utinomi, 1959).

New material:

1 to (B.L.I.H., Pyc. 76). Amadaiba, Sagami Bay, 62-65 m. 19-VII-62.

$1{ }^{\hat{\sigma}}$ (S.M.B.L., Pyc. 80). $4 \mathrm{~km}$ off Unoze, Tomioka, Amakusa Is., 35-40 fms. 10-IX-62, T. Habe coll. I ovig. $\delta^{x}, 2.3 \hat{0}, 1$ 우. Chijiwa Bay (Benthos survey sta. 6146 ), $40 \mathrm{~m}$. 17-VII-61, T. HABe coll.

10. Tomioka, Amakusa Is., on Dendronephthya, 63-72 m. X-63, T. HABE coll.

16. Chijiwa Bay (Benthos survey sta. 6143), 50 m. 24-VI-64, T. KIKUCHI \& A. TAKI coll. 
Distribution: Widespread from Madagascar to Japan, in rather shallow waters, mostly less than $100 \mathrm{~m}$ in depth.

\section{Anoplodactylus mamillosus STOCK イボソコウミグモ(新)}

Anoplodactylus mamillosus Sтоск, 1954: 72, figs. 31c-e \& 32.

Previous record: Sagami Bay, $300 \mathrm{fms}$ (dredged).

New material:

1 ( (S.M.B.L., Pyc. 77). Kozuchi-jima, Bisan Strait, Seto Inland Sea, 2 m. VII-65, T. YAMasu coll.

Remarks: This small specimen (about $1.5 \mathrm{~mm}$ long from the front of cephalon to the end of abdomen) quite agrees with Anoplodactylus mamillosus described from the deep water of Sagami Bay in having the peculiar ornamentation of setigerous tubercles on the scape of the chelifores, lateral processes and legs, although the segmentation of the trunk is obsolete. The ovigers are not seen. The propodal sole of the legs are strongly protruded and bears 3 spines. So it seems to be related also to A. minuitssimus STock recorded from Singapore, low tide.

\section{Family ENDEIDAE NORMAN \\ Genus Endeis PhILIPPI, 1843}

\section{Endeis mollis (CARPENTER) ミドリアバラムシ(改称)}

Phoxichilus mollis Carpenter, 1904: 183; Carpenter, 1907: 98; Loman, $1908: 77$.

Endeis mollis, Calman, 1923: 293, text-fig. 16; Ohshima, 1935a: 139: Stock, 1951: 17, figs. 23-24;

Bourdillon, 1954b: 4, figs. 1-3 (distribution map); STock, 1957a: 85; STock, 1965:31 (syn. et lit.).

Remarks: OHshima (1935a) recorded this circumtropical species from the coral reef of Ishigaki-jima, Ryukyu Islands, without any figure and descriptive note. The specimen was probably lost, so that his identification cannot be confirmed presently.

\section{Endeis meridionalis (BöHM) ミナミアバラムシ(新)}

Phoxichilus meridionalis BöHM, 1879a: 189, pl. 2, figs. 4-4b.

Endeis meridionalis, Calman, 1923: 291, fig. 15; Stock, 1965: 30.

Non Phoxichilus meridionalis, Loman, 1908: 78, pl. XI, figs. 153-155 (=Endeis biseriata Stock, 1968).

Previous records: Singapore and Tor in the Gulf of Suez (Bӧнм); Madras, India and Christmas Island, Indian Ocean (Galman); Nosy Bé, Madagascar, ca. $1 \mathrm{~m}$ (STOCK).

New material:

1 우 (S.M.B.L., Pyc. 85). Chijiwa Bay, Nagasaki-ken (Benthos survey sta. 6159), 60 m. 24-VI-61, T. HABE coll. 
Remarks: A single specimen examined agrees well with this species illustrated by Calman (1923, fig. 15) in having the spinose legs, the shuttlelike probosis, as long as the trunk and the obscurely bilobed collar at the base of the proboscis. This species is a new addition to the Japanese fauna.

\section{Family AMMOTHEIDAE DOHRN \\ Genus Achelia HODGE, 1864}

\section{Achelia superba (LoM AN) メナガイソウミグモ(内海)}

Ammothea superba Loman, 1911 : 11, pl. I figs. 14-15, pl. Il figs. 16-24; Fukui, 1918: 98; KisHida, 1927: 989, fig. 1906; OHshima, 1936: 866; Ohshima and Kishida, 1947: 1008, fig. 2860.

Achelia superba, HedgPeth, 1949: 287; Uтімомі, 1951: 160; Stock, 1954: 96; Utinomi, 1955a: 23,

fig. 13; Utinomi, 1959: 202; Utinomi, 1965: 336, fig. 21.

\section{New material:}

$70 \hat{0}$ (B.L.I.H., Pyc. 84). $1.5 \mathrm{~km}$ W of Kamegisyo, Sagami Bay, 60 m. 15-VII-63.

2 우우 (B.L.I.H., Pyc. -85). $2 \mathrm{~km}$ W of Kamegisyo, Sagami Bay, 60-80 m. 17-VII-63.

1 ovig. ¡ 2 우우 (B.L.I.H., Pyc. 95, 96). Kannonzukadashi, Amadaiba, Sagami Bay, 71 m. $19-$ VI-66.

Iô (S.M.B.L., Pyc. 74). Off Mitsuishi, Sagami Bay, 80 m. 17-WI-62, S. Gamo coll.

16. Chijiwa Bay, Nagasaki-ken (Benthos survey sta. 6304), 40 m. 29-VI-64, T. KikuchI and A. TAKI coll.

Many ơ 오. Chijiwa Bay, Nagasaki-ken, 40 to $60 \mathrm{~m}$. 1961-1963, T. Kikuchi and A. TAKI coll.

Distribution: Apparently endemic and abundant in moderate depths around Japan, from the east of Sakhalin to the west of Kyushu. Its bathymetrical range seems to be $40-180 \mathrm{~m}$. It has never been found in the intertidal region.

\section{Achelia echinata sinensis (LoU) トゲイソウミグモ(新)}

Ammothea echinata ssp. orientalis Losina-Losinsky, 1933: 55 \& 77, figs. 7-8.

Ammothea (Achelia) echinata var. sinensis Lou, 1936a: 19, text-figs. 7-9, pls. II-IV; OHsHimA, 1936: 865.

Achelia echinata ssp. nasuta MARcus, 1940: 84 \& 128 (renamed).

A. echinata orientalis, HedGPETH, 1949: 318.

A. echinata, Utinomi, 1954: 11, figs. 4-5; UтімомI, 1959: 201, fig. 1.

A. echinata nasuta, STоск, 1956: 98, fig. 16a.

A. echinata sinensis, NEsIs, 1967: 249.

? A, echinata var. japonica Ortmann, 1891: 164, pl. 24, fig. 6; Ohshima, 1936: 865.

New material:

$4{ }^{\star}{ }^{\star}$. Shinryu, Akkeshi Bay, 2 m. 18-VIII-63, S. Gamo coll.

10. Cape Chikyu-misaki, Muroran, Hokkaido, $13 \mathrm{~m}$. 27-VIII-63, S. Gamo coll.

20ð. Fukaura, Aomori-ken. 17-VIII-68, K. Konno coll. (Uchida et al., 1970: 10).

10. Tassha, Sado Is., Niigata-ken, intertidal. 4-VII-69, T. KITAMI coll.

$1 \hat{o}$ (S.M.B.L., Pyc. 64). Wakasa Bay, Fukui-ken, on the ascidian Herdmania momus. 12-VIII-55, T. TokIoKa coll.

1 ovig. of (B.L.I.H., Pyc. 76). Amadaiba, Sagami Bay, 62-65 m. 19-VII-62.

2 ovig. 3 . Minami-tannowa, Osaka Bay, intertidal. 8-VIII-60, I. Hamatani coll.

10. Kurushima Strait, Ehime-ken, Seto Inland Sea. VIII-56, K. Morikawa coll. 
19 (S.M.B.L., Pyc. 66). Nomo-saki, Nagasaki-ken, dredged by trammel net. 5-I-61, K. Matsubayashi coll.

1§̋. Tomioka, Amakusa Is., Low tide, on Sargassum-holdfast. 25-IV-64. T. KIKuchi coll.

Distribution: This oriental subspecies has been sporadically collected in few numbers around the coasts of Japan and North China, northwards to Hokkaido and Maritime territory of the Japan Sea. The bathymetrical range seems to be considerably wide, being from the shore down to $200 \mathrm{fms}$ (cf. Sтоск, 1956).

\section{Achelia alaskensis (COLE) エゾイソウミグモ(大島)}

Ammothea alaskensis Cole, 1904: 266, pl. XII fig. 4, pl. VXII figs. 4-12; Sснімкеwiтsch, 1929: 151, figs. 42-45; Oнsнima, 1933d: 144, fig. 1; Losina-Losinsky, 1933: 60, fig. 10; Ohshima, 1936: 866; OкUDA, 1940: 73 (larval development).

Achelia alaskensis, Utinomi, 1954: 14, figs. 6-7; Losina-Losinsky, 1961: 91.

\section{New material:}

1 ovig. 3 . Off Shinryu, Akkeshi Bay, Hokkaido, 2 m. 18-VIII-63. S. Gamo coll.

Distribution: Alaska (Cole), North Kuriles (Ohshima), Bering Sea and Okhotsk Sea (Schimkewitsah, Losina-Losinsky) and Hokkaido (Oкuda, Utrnomi). The bathymetrical range extends from the shore down to $180 \mathrm{~m}$ (cf. Losina-I.osinsky, 1961). The larvae inhabit usually the hydromedusa Polyorchis karafutoensis in Hokkaido (OKUDA). The adults, however, live on subtidal hydroids or algae (UtTinomi, Losina-Losinsky).

\section{Achelia bituberculata HEDGPETH フタイボイソウミグモ(新)}

Achelia bituberculata Hedgreth, 1949: 287, fig. 4 la-g; Sтоск, 1954: 94, fig. 44; Utinomi, 1962: 97, fig. 4.

Previous records: All are confined to the Miura Peninsula, east of Sagami Bay, at low tide.

\section{New material:}

1 ơ (B.L.I.H., Pyc. 77). Kurosaki, Miura Peninsula, shore. 20-VI-62.

$1 \sigma^{*}$ (B.L.I.H., Pyc. 86). Kasa-jima, Miura Peninsula, shore. 19-VII-63.

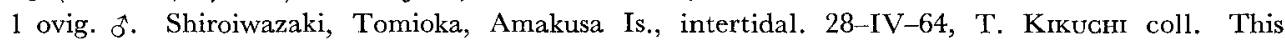
is the southernmost record of this species.

\section{Achelia nana (LoMAN) ヨットゲイソウミグモ(新)}

Ammothea nana Loman, 1908: 60, pl. I, figs. 1-13.

Achelia nana, Sтоск, 1953b: 300, fig. 14; Stock, 1954: 97; Sтоск, 1965: 15.

Previous records: Malay Archipelago, 0-23 m (Loman, STock), Madagascar, ca. $1 \mathrm{~m}$ (STоск, 1965).

New material:

$3{ }^{*}{ }^{*}$ (S.M.B.L., Pyc. 86). Chijiwa Bay, Nagasaki-ken (Benthos survey sta. 6303), 30 m. 20VIII-63, T. KIKUCHI and A. TAKI coll. 
Remarks: The present record extends its geographical range northward to Kyushu, western Japan and its bathymetrical range slightly downward.

\section{Achelia kiiensis UTINOMI キイイソウミグモ(新)}

Achelia kiiensis Utinomi, 1951: 161, fig. 1.

Previous record: Tanabe Bay, Wakayama-ken, 5-10 m.

\section{Achelia ohshimai UtinomI オオシマイソウミモグ(内旗)}

Achelia ohshimai Uтіломi, 1951: 163, fig. 2; Utinomi, 1954: 18, fig. 8; Uтімомг, 1965: 336, fig. 20.

Previous records: Hatake-jima in Tanabe Bay, Wakayama-ken, intertidal (UTinomi, 1951); Akkeshi, Rishiri Is. and Monbetsu (all of Hokkaido), intertidal (UTinomi, 1954).

New material:

10. Fukaura, Aomori-ken, intertidal (in front of the laboratory). X-68, K. Konno coll. (UchidA et al., 1970: 10).

\section{Achelia segmentata Utinomi アシナガイソウミグモ(新)}

Achelia segmenlala Utinомт, 1954: 20, fig. 9; Nesss, 1967: 249.

Previous records: Akkeshi, Hokkaido, on red algae (Utinomi); Possjet Bay, NW of the Japan Sea, on red algae and Strongylocentrotus nudus (Nesis).

\section{Genus Ammothella VERRILL, 1900}

\section{Ammothella biunguiculata (DOHRN) フタッメイソウミグモ(内海)}

Ammothea bi-unguiculata Dohrs, 1881: 158, pl. 8, figs. 1-3; Oнsнiм., 1927b: 612, fig. 4; OHshima, 1927d: 385, pl. VII, figs. 7-8.

A. (Ammothella) bi-unguiculata, Bouvier, 1923: 52, figs. 49-49a; Ohshima, 1936: 866.

Ammothella bi-unguiculata, Hedgpeth, 1941: 255 \& 259; Hulton, 1942b: 297, pl. 42 (lit.); Bourdillon, 1954a: 151, pls. I-II; Utinomi, 1965: 336, fig. 22; Sтоск, 1968: 14.

New material:

1. Fukaura, Aomori-ken, intertidal. 10-VI-68, IX-68, K. Konno coll. (Uchida et al., 1970: 10). Many fo (S.M.B.L., Pyc. 61). Tomogashima, south of Osaka Bay. 29-IV-57, I. Hamatani coll. Many oft (S.M.B.L., Pyc. 8). Hatake-jima in Tanabe Bay, under stones. 28-VII-53, H. UTINOMI coll.

10. Yuzaki, Shirahama, Wakayama-ken, intertidal. 20 29-VII-64, I. HAMATANi coll.

19. Ezura, Shirahama, Wakayama-ken, intertidal. 26-VI-64, I. HAMATANi coll.

10. Shiroiwasaki, west coast of Tomioka, Amakusa Is., under stones. 27-VIII-61, T. Habe coll.; 19-VII-63, T. KIKUCHI coll. 
407 (S.M.B.L., Pyc. 70). Sashiki, Kumamoto-ken, under stones. 22-IX-61, T. HABE coll. $4 \hat{\delta} \hat{\delta}, 1$ ㅇ. Tsuji-shima, east of Tomioka, Amakusa Is., under stones. VII-57, T. HABE coll. 20추 5우우. Nomosaki, Nagasaki-ken, under stones. 3-XI-60, K. Matsubayashi coll.

궁 (M.M.B.S., No. 58-1). Mukaishima, Hiroshima-ken, Seto Inland Sea. 15-XI-62, A. Inaba coll. (INABA, 1963: 206).

Distribution: Cosmopolitan in warm intertidal waters. Very common around the coasts of Main Islands of Japan. Also some local forms are recorded from the Hawaiian Islands and Australian waters (Hilton, 1942; Williams, 1939; Clark, 1963).

\section{Ammothella indica STOCK クダトゲイソウミグモ(新)}

Ammothella indica Sтоск, 1954: 113, figs. 54-56c, 57a-c; Sтоск, 1959: 551; Uтімомт, 1959: 203, figs. 2-3; Стоск, 1968: 11.

Previous records: Sunda Straits, $30 \mathrm{~m}$, Singapore, low tide and south of Bali Is., 19 m (Stock, 1954); Durban Bay, South Africa, from ships' hulls (Stock, 1968); south of Enoshima, Sagami Bay, depth unknown (Utrinomi).

\section{Genus Nymphonella OHshima, 1927}

\section{Nymphonella tapetis OHSHIM A カイヤドリウミグモ(大島)}

Nymphonella tapetis OHshima, 1927a: 262, figs. 1-4; Oнshima, 1927c: 367, pls. 5-6; Ohshima, 1933a: 53, figs. 1-4; Ohshima, 1933e: 94; Ohshima, 1935b: 95, figs. 1-4; Ohshima, 1936: 846; Arita, 1936 : 469, figs. 1-3, pl. 32 (malformation); Arita: 271, figs. 1-7 (movement); OHshima, 1943: 374 , 1937: 1616, figs. 1-4, pl. 80 (life history); Oнsнima, 1942b: 520, figs. 1-2 (malformation); Oнsнiмa, figs. 3-4 (malformation); Calvez, 1950: 114, fig. 1 ( $=$. lecalvezi Guille et Soyer, 1968, renamed as a separate sp.)

Previous records: OHshima repeatedly reported this unique pycnogonid from various localities in Kyushu (Najima in Fukuoka Bay as the type locality, Kazusa in Shimabara Peninsula and Tomioka in Amakusa Islands). The larvae were at first found infesting the bivalves Tapes philippinarum (=Tapes japonica) and Protothaca edoensis. The adults, however, live free in the shore sands. Hitherto this pycnogonid has not been found elsewhere in Japan proper. This may be due to its interstitial habit which may escape notice in mere shore-collecting.

Zoogeographically interest is the fact that a closest specimen found in plankton tows at the Bay of Banyulus on the Mediterranean coast of France by Le CALvez (1950) looks alike, but later regarded as a separate species by GuIlle et Soyer (1968) and renamed as $N$. lecalvezi (Also see Stock, 1968b). A third species $N$. lambertensis STock was described from Lambert's Bay, South Africa, $15 \mathrm{~m}$ in depth.

New material: Professor S. Miyake of Kyushu University generously presented two mounted preparats of Nymphonella tapetis OHsHIma selected from a few lot of preparats originally prepared by Dr. OHshima himself or ArIta and still retained in his institute for permanent custody. So I designated here one of the two preparats, containing a large-sized young male, probably obtained at the type locality, as 
the lectotype (S.M.B.L., Type 235) and deposited in the museum of the Seto Marine Biological Laboratory, together with another preparat containing a hatched larva.

\section{Genus Ascorhynchus G. O. SARS, 1877}

\section{Ascorhynchus auchenicus (SLATER) フタトゲトックリウミグモ(内海)}

Parazetes auchenicus Slater, 1879: 281; Hoek, 1881: 26; Shishido, 1899: 199.

Ascorhynchus bicornis ORTMAnN, 1891: 162; Shishido, 1899: 199.

As. leptorhynchus Ноек, Fuкu, 1918: 17-18, fig. from Hojyo, Awa (nec Новк).

As. ramipes, LomAn, 1911: (part.)

As. minutus, Schimkewitsch, 1929: 111, figs. 26-27 (nec Нoek).

As. auchenicus, Galman, 1922: 199, figs. 1-4 (part.); Ohshima, 1936: 864; Hedgreth, 1949: 291 (lit.); Uтімомi, 1965: 337, fig. 27.

As. auchenicum, Sтоск, 1954: 124, figs. 59-60 (syn. et lit.); Uтпомі, 1959: 206, fig. 4A (syn. et lit.).

New material:

1ô (B.L.I.H., Pyc. 76). Amadaiba, Sagami Bay, 62-65 m. 19-VII-62.

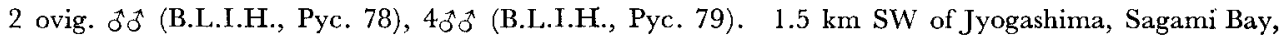
70-75 m. 19-XII-62.

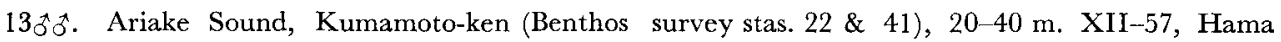
Branch of Seikai Fish. Res. Inst. coll.

$2 \sigma^{\star}$ (S.M.B.L., Pyc. 69). Tomioka, Amakusa Is., 20 m. 19-x-59, 12-VII-61, T. HABE coll.

Many ơㅇ (S.M.B.L., Pyc. 71). Off Sakasegawa, Amakusa Is., 22-36 m. 11-XII-61, T. HABE coll. 1 ovig. $\tilde{\sigma}$. Tomioka Bay, Amakusa Is., 16 m. 30-IV-62, T. Kıкuch coll.

$7 \hat{o} \hat{o}$. Off Nishihama, Tomioka, $40 \mathrm{~m} .26-\mathrm{VIII}-56$, T. Kıкuchi coll.

5 ovig. $\widehat{\delta} \hat{\delta}, 1$ ․ Chijiwa Bay, Nagasaki-ken (Benthos survey sta. 6303). 17-I-63, T. HABE and others coll.

10. Off Shinryu, Akkeshi Bay, 2 m. 18-VIII-63, T. Gamo coll.

1 ovig. 3. Chikyu-misaki, Muroran, Hokkaido, $13 \mathrm{~m}$. 27-VIII-63, T. GaMo coll.

Distribution: Very prevalent and abundant in coastal waters of Japan proper. The bathymetrical range is very wide, extending from $2 \mathrm{~m}$ down to $540 \mathrm{~m}$.

\section{Ascorhynchus ramipes (BöHM) ヒモッキトックリウミグモ(新)}

Gnaptorhynchus ramipes Böнм, 1879b: 56, fig. 1; Sнisнido, 1899: 199.

Ascorhynchus ramipes, ORtMann, 1891: 161, pl. 24, fig. 4; Loman, 1911: 6 (part.); Fukui, 1918: 8;

Ohshima, 1936: 865; Hedgpeth, 1949: 292 (lit.); Utinomi, 1959: 207, fig. 4B (syn.); Utinomi, 1926: 99 .

As. ramipes var, tsingtaoensis Lou, 1936a: 3, figs. 2-5, pl. 1.

As. latus Calman, 1923: 270, figs. 2-3.

As. latum, Sтоск, 1954: 128, fig. 63a-c.

New metarial:

6 ovig. $\hat{\jmath} \hat{\jmath}, 2 q q$ (S.M.B.L., Pyc. 76). Tsuyazaki, Fukuoka-ken, 30 m, dredged. 28-IV-63, S. GAMo coll.

2 ovig. $\widehat{\partial}$. Tomoe Cove, Tomioka, Amakusa Is., 10-20 m, dredged. 30-VI-32, H. Oнsнiмa coll. 
Distribution: Apparently shallow-water species, commonly distributed from Tokyo and Sagami Bays (Böнm, Ortmann, Fukui, Loman, Hedgreth, Utinomi) to Kyushu (HedGPeTh and the present paper). Further recorded from Tsingtao, North China (Lou), Gulf of Siam (Stock) and Gulf of Manaar, India (Calman).

\section{Ascorhynchus japonicus IvES ヤマトトックリウミグモ(内海)}

Ascorhynchus japonicus Ives, 1892: 219, pl. 12, figs. 4-10: Loman, 1911: 5; Fukui, 1918: 98; Ohshima, 1936: 865; Hedgpeth, 1949: 292; Utinomi, 1951: 166; Losina-Losinsky, 1961: 107, fig. 25; UTinomi, $1965: 337$, fig. 26.

As. japonicum, Sтоск, 1954: 126, figs. 61-62; Uтімомі, 1955a: 24; Uтімомі, 1959: 205.

New material:

1 ovig. $\sigma^{\hat{\theta}}$ (B.L.I.H., Pyc. 92). $2.5 \mathrm{~km}$ WNW of Jyogashima, Sagami Bay, 65-75 m. 13-II-65. 1 ovig. $\widehat{\partial}$ (B.L.I.H., Pyc. 93). 2 km WNW of Jyogashima, Sagami Bay, 53-55 m. 13-II-65. 2 ovig. oे $^{t}$ (B.L.I.H., Pyc. 94, 95). Amadaiba, Kannonzukadashi, Sagami Bay, 71 m. 19-VI-66.

Distribution: This large-sized species seems to be rather common in moderately deep waters along the Pacific coast of Japan. The bathymetrical range extends from $65 \mathrm{~m}$ to $360 \mathrm{~m}$ in Sagami Bay. HedG PETH (1949) established its bathymetrical range as $88-918 \mathrm{fms}$ from the Albatross collecting records. Losina-Losinsky (1961) recorded also from the east coast of Northern Sakhalin in the depths of 168-540 m.

\section{Ascorhynchus cryptopygius ORTMANN チビオトックリウミグモ(新)}

Ascorhynchus cryptopygius Ortmann, 1891: 159, pl. 24, fig. 2; Shishido, 1899: 199; Loman, 1911: 7; Fuкur, 1918: 98; Онsнiма, 1936: 865. As. cryptopygium, Sтоск, 1954: 121, fig. 58; Uтімомі, 1959: 25, fig. 14.

Distribution: Apparently confined to Sagami Bay, as shown by all previous records. The bathymetrical range is shown as follows: $60 \mathrm{fms}, 100 \mathrm{fms}$ and $150 \mathrm{fms}$ (Ortmann); 80-120 fms (Stock); $251 \mathrm{~m}$ (Utinomi).

\section{Ascorhynchus glabroides ORTMANN イガトックリウミグモ(新)}

Ascorhynchus glabroides Ortmann, 1891: 160, pl. 24, fig. 3a-b; Shishido, 1899: 199; Fuku1, 1918: 98; Loman, 1911: 7; Ohshima, 1936: 865; Hedgpeth, 1949: 293; Utinomi, 1951: 166; Utinomi, 1959: 25.

Previous records: Sagami Bay, depth unknown (Loman); off Minabe, Kii Channel, 100-200 m (Utinomi); west of Kyushu, 40-50 fms, $139 \mathrm{fms}$ (Ortmann, Hedgreth).

New material:

3 ovig. $\delta^{\wedge} o^{*}, 2$ 우. Bingo-nada, Seto Inland Sea, depth unrecorded, IV-50, Iw. TAki coll.

$5 \sigma^{\star}$ (S.M.B.L., Pyc. 88). Off Nishihama, Tomioka, Amakusa Is., 30 m. 25-VIII-61, T. Habe coll. 


\section{Ascorhynchus glaberrimus SCHIMKEWITSCH スベスベトックリウミグモ(新)}

Ascorhynchus glaberrimus Sсhімкеwiтsch, 1913: 242, pl. 3a, figs. 8-14; Sсhiмкewitsch, 1929: 107, figs. 23-25; Ohshima, 1936: 865; Hedgreth, 1949: 293.

As. glaberrimum, Uтімомі, 1955a: 26, fig. 15; Uтімомі, 1959: 208.

Previous records: Nagasaki, western Kyushu, depth unrecorded (SaHimkewitsch, Hedgpeth); near Mishima, Yamaguchi-ken (Soyo-maru Sta. 485), 93 m (Utinomi, 1955); Sagami Bay, 50-78 m (Uтімомi, 1959, 1962).

New material:

$1 \hat{\circ}$ (B.L.H.I., Pyc. 88). $1.4 \mathrm{~km}$ W of Jyogashima, Sagami Bay, 51-56 m. 11-II-64.

10. Off Nabeta Bay, Shimoda, Izu Peninsula. V-61, S. Konuma \& K. Sekiguchi coll.

2웅. Agenoshô, Suô-Oshima, Yamaguchi-ken, Seto Inland Sea, shore. 1953, K. Kono coll.

$2 \widehat{o ̂}^{\hat{o}}$ (S.M.B.L., Pyc. 68). Tomioka, Amakusa Is. (Benthos survey, sta. 6012), $12 \mathrm{~m} .15-\mathrm{VI}-60, \mathrm{~T}$.

Habe coll. $1{ }^{*}$. Tomioka Bay, Amakusa Is., 24 m. 26-IX-61, T. HABE coll.

Many ơ?. Chijiwa Bay, Nagasaki-ken (Benthos survey sta. 6302, 6303, 6306), 16-80 m. 16-IX63, 10-III-64, 8-V-69, T. КікUсні \& A. TAкі coll.

Distribution: As shown by all the previous and present records, this is evidently a shallow-water species, apparently endemic in Japan proper.

\section{Ascorhynchus tuberosus UTINOMI イボトックリウミグモ(新)}

Ascorhynchus tuberosum Uтімомт, 1962: 100, figs. 5-6.

Previous record: $2.5 \mathrm{~km}$ NW of Kamegisyo, Sagami Bay, 50-60 m (type locality alone).

\section{Genus Cilunculus Loman, 1908}

\section{Cilunculus armatus (BöHM) ッノウミグモ(内海)}

Lecythorhynchus armatus BöHM, 1879c: 141; SHISHIDo, 1899: 199.

Parazetes pubescens OrTmann, 1891: 163, pl. 24, fig. 5a-d.

Ammothea armata, Sснімкеwiтsch, 1909: 4, fig. 2.

Cilunculus armatus, Loman, 1911: 9, pl. 1, figs. 1-8; Fukur, 1918: 98; OHshim A, 1936: 866; Hedgreth, 1949: 294, fig. 43; Utinomi, 1955a: 27, fig. 16; Utinomi, 1959: 205; Losina-Losinsky, 1961 : 108; Utinomi, 1965: 337, fig. 25.

Cilungulus (sic) armatus, Schiмкеwiтsch, 1929: LXXVI, fig. 5A-G, 81, figs. 18, 19A-G, 20.

Previous records: Enoshima, Sagami Bay (Вӧнм); Kadsiyama (=Katsuyama), mouth of Tokyo Bay, shallow depth (Ormann); Enoshima, Dzushi and Misaki, all of Sagami Bay, 80-131 m (LomaN); off Sunosaki in Sagami Bay, $251 \mathrm{~m}$ and Kamegisyo in Sagami Bay, 8 fms (Uтіломі); SW of Omae-zaki, Ensyu-nada, 36-48 fms, southern coast of Hokkaido, 175-349 fms and east of southern Sakhalin, Ohkotsk Sea, $73 \mathrm{fms}$ (Hedg Peth) ; Okhotsk Sea, $101 \mathrm{~m}$, east of .Shikotan and Itrup Is., 137188 m (Losina-Losinsky). 
New material:

2 ovig. $\widehat{\sigma}^{\hat{\sigma}} \hat{\sigma}, 5 \sigma^{\hat{\alpha}}$ (B.L.I.H., Pyc. 89). Minami-amadaiba, Sagami Bay, 190-250 m. 20-VII-64.

$2 \hat{o} \hat{o}$ (S.M.B.L., Pyc. 73). Off Yoshihama, Sagami Bay, 20 m. 8-VI-57, S. Gamo coll.

$1{ }^{\circ}$ (S.M.B.L., Pyc. 79). Off Nishihama, west coast of Tomioka, Amakusa Is., 40 m. 26-VII-56, T. Habe coll.

Many 3̧ T. Chijiwa Bay, Nagasaki-ken (Benthos survey sta. 6302, 6303, 6139, 6143), 30-50 m. 1961 1964, Т. НАвE, Т. КікUС̆ \& А. ТАKI coll.

Distribution: Quite common in moderate depths, from the Okhotsk Sea to Kyushu. Its bathymetrical range is considerably wide, ranging from 30 to $618 \mathrm{~m}$. So it cannot be said 'a cold-water form' (Hedgpetr, 1949: 294).

\section{Genus Nymphopsis HaSweld, 1884}

\section{Nymphopsis muscosa LoMAN トゲウミグモ(内海)}

Nymphopsis muscosus Loman, 1908: 52, pl. 13, figs. 175-188; Loman, 1911: 11 ; Fukur, 1918: 99; Ohshima, 1936: 864.

N. muscosa, Stock, 1953b: 307; Sтоск, 1954: 121; Uтимомт, 1959: 205; Utтnомт, 1965: 337, fig. 24.

Previous records: Sulu Islands, 16-23 m, Malay Archipelago, 36-73 m (Loman); NW of Borneo, 20-29 fms (Sтоск, 1953b); off Jolo, Sulu Is., 25 fms (STock, 1954); Sagami Bay, 50-130 m (Loman, 1911); Sagami Bay, 7-8 fms, 17 m (Utinomi).

\section{Genus Heterof ragilia HedgPeTH, 1943}

\section{Heterofragilia amica STOCK ゴトウウミグモ(新)}

Heterofragilia amica Sтоск, 1954; 136, figs. 67-68; Uтімомı, 1955a: 28, fig. 17.

Previous records: SW of Gotô Islands, west of Kyushu $\left(32^{\circ} 15^{\prime} \mathrm{N}, 128^{\circ} 12^{\prime} \mathrm{E}\right), 90$ fms (Sтоск); off Sata-misaki, SW of Kyushu $\left(30^{\circ} 45^{\prime} \mathrm{N}, 130^{\circ} 40^{\prime} 40^{\prime \prime} \mathrm{E}\right), 203 \mathrm{~m}$ (UTINOMI).

\section{Genus Scipiolus Loman, 1907}

56. Scipiolus spinosus UTINOMI トゲチビウミグモ(新)

Scipiolus spinosus UтімомI, 1955a: 31, fig. 19.

Previous record: Seno-umi in Suruga Bay (Soyo-maru Sta. 284), $71 \mathrm{~m}$.

\section{Scipiolus validus STOCK ケアシチビウミグモ(新)}

Scipiolus validus Sтоск, 1957a: 91, figs. 8-10b, d.

Previous record: Uraga Strait, entrance to Tokyo Bay, $21 \mathrm{fms}$. 


\section{Genus Lecythorhynchus BöHM, 1879}

\section{Lecythorhynchus hilgendorfi (BöHM) シマウミグモ(大島)}

Corniger Hilgendorfi Böнm, 1879a: 187, pl. 2, figs. 3-3d.

Leçvthorhynchus Hilgendorf, Böнм, 1879b: 140; Sніsншо, 1899: 199; Loмan, 1911: 8, pl. 2, figs. 28-29; Fukur, 1918: 99.

L. hilgendorfi, Oнsнiма, 1927a: 381, pl. 7, figs. 1-6; Oнsнiма, 1927b: 610, figs 1-3; Sснімкеwitsch, 1929: 54, figs. 10-11; Oнshima, 1936: 867; Lou, 1936b: 133, figs. 1-4, 5A and pls. 11-13;

Hedgpeth, 1949: 296, fig. 44a-b; Utinomi, 1951 : 166; Utinomi, 1959: 209, figs. 5-6 (syn.) ; LosinaLosinsky, 1961: 53; Utinomi, 1965: 336, fig. 23; Nesis, 1967: 250.

L. marginatus Cole, 1904: 260, pl. 11, figs. 1-2, pl. 15, figs. 1-8; Helfer, 1938: 184; Schimkewitsch, 1929: 50, figs. 7-9; Losina-Losinsky, 1933: 61; Hilton, 1939a: 34; Hedgpeth, 1941: 255; Hilton, 1943b: 4; Sтоск, 1954: 139, fig. 69.

New material:

10. Akkeshi Bay, Hokkaido, shore. 18-VIII-63, S. Gamo coll.

16. Nonai Inlet, Aomori Bay, on Sargassum. 2-6-VIII-60, 5-6-IX-60, H. SANdo coll.

20 . Fukaura, Aomori-ken, intertidal. 10-VI-68, K. Konno coll. (Uahida et al., 1970: 10).

$2 \delta$. . Kamo-ko, abrackish lake on the east coast of Sado Is., Niigata-ken. 8-XI-67. T. KITAmr coll. $3 \hat{\jmath}$. Shimoda, Izu Peninsula. V-61, K. Sekiguchi coll.

10 (S.M.B.L., Pyc. 64). Wakasa-ohshima, Wakasa Bay, on ascidians. 1958, T. Tokioka coll.

Many of. Ezura, Yuzaki and Shirahama, Wakayama-ken, under stones. 20 26-VI-64, I. HAMATANI coll.

Many ơ오 (S.M.B.L., Pyc. 61). Minami-tannowa, Osaka Bay, intertidal. 8-III-51, 28-III-52, 7-II54, 15-VIII-54, 19-VIII-55, 29-IV-57, 25-VII-57, 28-III-60, Iw. Hamatani coll.

중 (M.M.B.S., No. 58-2). Mukaishima, Hiroshima-ken, Seto Inland Sea. 15-XI-62, A. INABA coll. (INABA, 1963: 205).

4ô. Imabari, Kurushima Strait, Ehime-ken, Seto Inland Sea. VIII-56, K. Morikawa coll.

1 ovig. $\hat{o}$. Tsuji-shima, Tomioka, on Sargassum holdfast, intertidal. 11-VI-65, T. Kıкuchi coll.

Distribution: Very common on all the coasts of Japan at low tide. This intertidal species is a well known, amphi-northern Pacific form, but curiously hitherto unknown from any tropical regions. Its habitat is sheltered, so that the larvae often live on benthic animals or algae on the shore gravels or stones.

\section{Lecythorhynchus hedgpethi UTINOMI エナガシマウミグモ(内海)}

Lecythorhynchus species HedGPETH, 1949: 296, fig. 44e-f.

L. hedgpethi Uтімомі, 1959: 213, figs. 7-9; Utinomi, 1962: 103.

Previous records: SW of Omae-zaki, Ensyu-nada (Albatross Sta. 3730), 34-37 fms (HedGpeth); Sagami Bay, 8-80 m, 65-90 m (Utinomi).

Genus Tanystylum, 1879

\section{Tanystylum anthomasthi HEDGPETH ウミトサカフトウミグモ(内海)}

Tanystylum anthomasthi HedGeth, 1949: 297, fig. 45; Utinomi, 1954: 23, text-figs. 10-11, pl. I, fig. 
2, Uтімомі, 1965; 338, fig. 29.

T. anthomasti, Hedgpeth, 1963: 1339, figs. 7, 10 (renamed).

Distribution: Probably amphipacific boreal arctic species, as it has been recorded from Akkeshi Bay (Hedgpeth, Utinomi), Point Barrow, Alaska and Coos Bay Entrance, Oregon (Hedgreth, 1963). The host varies locally, as it has been found on Metalcyonium pacificum (YAmada) only in Akkeshi Bay, Hokkaido, while in Alaska and Oregon it has been found on the nephtheid octocoral Gersemia rubiformis (EHRENBERG).

\section{Tanystylum scrutator STOCK ヒヨットコフトウミグモ(新)}

Tanystylum scrutator STock, 1954: 142, fig. 70.

Previous record: Misaki, east of Sagami Bay, shore, on coralline algae.

\section{Family AUSTRODECIDAE STOCK}

Genus Austrodecus Hodgson, 1907

62. Austrodecus tubiferum STOCK スイクチゥミグモ(内海)

Austrodecus gordonae (part.) Sтоск, 1954: 153, fig. 76e.

A. tubiferum Sтоск, 1957b: 75, fig. 43 (renamed).

Previous record: Okinose Bank in Sagami Bay, 100 frns (type locality).

\section{Family COLOSSENDEIDAE HoEK}

Genus Colossendeis JARZYNSKY, 1870

63. Colossendeis dofleini LoMAN フクレクダウミグモ(新)

Colossendeis dofleini Loman, 1911: 4, pl. 1, figs. 9-13; Fukur, 1918: 98; Ohshima, 1936: 867; HedgPeth, 1949: 300, fig. 47a-d; Utinomi, 1951: 167; UтіломI, 1955a: 33.

New material:

$4 \hat{o} \hat{o}$. North of Unoze, Tomioka, Amakusa Is. (Between Benthos survey sta. 6145 and 6304), 40 m. 16-I, V-64, T. KIKUahI coll.

10. Chijiwa Bay (Benthos survey sta. 6303), $40 \mathrm{~m}$. 16-XII-63, T. Kikuchi and A. TAKI coll.

Distribution: Common from the south of Kyushu as far as the south of Kamchatka Peninsula (Losina-Losinsky). The bathymetrical range is also wide, ranging from $20 \mathrm{~m}$ down to $909 \mathrm{~m}$ (505 fms) (Hedgpeth, Utinomi).

\section{Colossendeis chitinosa HILTON チビオクダウミグモ(新)}

Colossendeis chitinosa Hilton, 1943b: 4; Hedgreth, 1949: 301, fig. 47e-h; Stock, 1954: 161, fig. 79; Utinomi, 1955: 34, fig. 20; Losina-Losinsky \& Turpaeva, 1958: 23, fig. 1; Utinomi, 1962: 103; Losina-LosINSKY, $1961: 109$. 
New material:

1 specimen (B.L.I.H., Pyc. 80). $1.5 \mathrm{~km}$ SW of Jyogashima, Sagami Bay, 70-75 m. 19-XII-62. 10. Chijiwa Bay (Benthos survey sta. 6119), $31 \mathrm{~m} .6-\mathrm{IX}-61, \mathrm{~T}$. HABE coll.

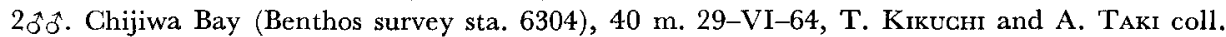
10. Chijiwa Bay (Benthos survey sta. 6303), $20 \mathrm{~m}$. 17-V-63, T. KІкUсні coll.

Distribution: Common in the northwestern part of the North Pacific, ranging from the Aleutian Islands to the west of Kyushu. Its type locality is U.S. Nat. Mus. Sta. 3500 (exact locality unmentioned) and Sta. $3603\left(58^{\circ} 23^{\prime} \mathrm{N}, 170^{\circ} 21^{\prime} \mathrm{W}, 1771\right.$ fms) which lie approximately on the south of the Aleutian Islands. Later records, however, show much shallower depths in occurrence; namely, 390-428 fms in Ensyunada, $31 \mathrm{fms}$ in Suruga Bay (Неdgpeth, 1949), and 90-132 m (Utinomi, 1955), and 70-80 $\mathrm{m}$ in Sagami Bay (Uтіломr, 1962). The present records from Chijiwa Bay, western Kyushu show much shallower occurrence southwards.

Remarks: The remaining representatives of the genus recorded from Japanese waters, such as $C$. colossea Wruson (=C. gigas Hoek), C. macerrima Wilson $(=C$. leptorhynchus Hoex), C. japonica Hoek, C. angusta Sars, C. nasuta Hedgpeth, C. brevitarsis Losina-Losinsky, $C$. orientalis Losina-Losinsky, $C$. bicornis Turpaeva, etc. appear to be true deep-water dwellers, since they have not been recorded from shallower waters than at least $500 \mathrm{~m}$ in depth.

\section{Family PYCNOGONIDAE WILSON}

\section{Genus Pycnogonum BRÜNNICH, 1764}

\section{Pycnogonum tenue (SLATER) KISHIdA ヨロイウミグモ(岸田)}

Pycnogonum littorale Ström var. tenue Slater, 1879: 283; Ortmann, 1891: 167; Shishido, 1899: 200; Fukui, 1918: 99; SсHimкеwitsch, 1929: 15.

P. tenue Kishida, 1927: 989, fig. 1905; Ohshima, 1936: 867; Hedgpeth, 1949: 303, figs. 48b, 50c; Sтоск, 1954: 162, fig. 80; Uтімомі, 1955a: 36, figs. 22-23; Uтімомі, 1959: 216; Uтіnомi, 1965: 338, fig. 31 .

Previous records: Sagami Bay, 100 fms (Ortmann); Sagami Bay, 250-300 m (Utinomi, 1959); Suruga Bay, 60-125 fms (Hedgreth); Kii Channel, $251 \mathrm{~m}$ (UtiNomi, 1955a); south of Kagoshima, Kyushu, 152 fms (НEDGPeth); southwest of Goto Is., Kyushu, 95-115 fms (Hedgpetri, Stogk and Slater).

New material:

1 (우 (S.M.B.L., Pyc. 79). Off Nishihama, west coast of Tomioka, Amakusa Is., 40 m. 26-VII-56, T. HABE coll.

1․ Chijiwa Bay (Benthos survey sta. 56). 6-X-56, T. HABE coll.

30ㅊㅇ, 4우우. Ch ijiwa Bay (Benthos survey sta. 6122, $27 \mathrm{~m}$; sta. 6166, $66 \mathrm{~m}$; sta. 6306, $82 \mathrm{~m}$ ). 9VIII-61, T. HaBe coll. 11-VIII-61, T. HABe coll. 10-III-64, T. KiKUGH \& A. TAKI coll.

Remarks: Hitherto recorded from moderate depths (40 to $152 \mathrm{fms}$ after Sтоск) of Japan proper only. 
66. Pycnogonum ungellatum LoMAN ゲホウヨロイウミグモ(岸田)

Pycnogonum ungellatum Loman, 1911: 7, pl. 2, figs. 25-27; Fukui, 1918: 99; Kishida, 1927: 989; OHSHIMA, 1936: 868; OHshima and Kishida, 1947: 1010; HedgPeth, 1949: 304, figs. 48c, 50e-g; LosinaLosinsky, 1961: 111, fig. 27.

Previous records: Sagami Bay, depth unrecorded (LomaN); south of Kamchatka Peninsula (Albatross Sta. 4803, 4804), 229 fms (Hedgreth); Kurile Islands, Okhotsk Sea, $100 \mathrm{~m}$ (Losina-Losinsky).

Remarks: This species has not yet been found in shallow waters of Japan, outside of the type locality (Sagami Bay). Presumably it appears to be a true boreal species like $P$. stearnsi Ives, which was ever reported from the North Kuriles by Ohshima (1933d), after the records of Hedgpeth and Losina-Losinsky.

67. Pycnogonum benokianum OHSHIM A ベノキヨロイウミグモ(大島)

Pyonogonum benokianum Ohshima, 1935a: 137; Ohshima, 1936: 868; Ohshima and Kishida, 1947: 1010, fig. 2866; Неdgpeth, 1949: 304, fig. 49 (reproduced only).

Previous record: Benoki, Okinawa Island, found as infesting a sea anemone Phellia (= Telmatactis) decora (EHREnBERG).

\section{Zoogeographical and Bathymetrical Remarks}

As were comprehensively discussed by Hedgreth (1949: 233-245) and Stock (1953b: 277-282; 1954: 3-11), the Japanese pycnogonid fauna is practically rich, if not the richest of the world. As far as the eulittoral or shallow-water pycnogonids are concerned, the faunal components are much diverse in relation to the location of the Japanese Islands lying in a continual chain between a boreal arctic region and a tropical region, so that the marine fauna represents an intermingling of coldand warm-water species. Moreover, the rugged and indented nature of the Japanese coasts provides a complex of diversing littoral species in addition to endemic elements.

The Pacific coasts of the Japanese Mainland is warmed by the Kuroshio, a northward flowing warm current which turns eastward at about latitude $36^{\circ} \mathrm{N}$, where the cold Oyashio Current, which originates in the Bering Sea and the Okhotsk Sea flows southward, and makes the coastal waters of northern Japan considerably colder than those of southern Japan. According to EkMAN (1953, p. 22), the boundary between the northern, cold-temperate fauna and the southern, subtropical fauna lies about latitude $36^{\circ} \mathrm{N}$ (approximately Cape Inubô-zaki).

Sagami Bay. This bay lying on eastern Honsyu Island thus belongs to the southern subtropical region zoogeographically. The water of the bay is indeed warm in the upper layer, as furnished by the warm-water mass, while cooler in the 
deeper layer of the offshore region where the offshoot of the cold Oyashio Gurrent is assumed to descend below the warm upper water mass.

As already summarized, the pycnogonid fauna of the Sagami Bay and its adjacent waters is, as far as known at present, apparently the richest of all regional faunae in Japanese waters, as represented by more than 17 genera and 46 species (UTINomi, 1959: 216-220). As shown in the faunal list mentioned above, some of the true boreal arctic species may descend in deeper area of the bay. Besides, the deeper layer is predominated by deep-water dwellers like Nymphon, Colossendeis and Ascorhynchus.

Hokkaido. As might be expected, the pycnogonid fauna on the southern coast of Hokkaido is essentially boreal, and especially closely related to that of the Kurile-Aleutian Island chain, and then to that of the Pacific coast of North America eastward; for instance in the occurrences of Decachela discata, Achelia alaskensis, $A$. echinata, Tanystylum anthomasthi and Lecythorhynchus hilgendorfi of amphi-North-Pacific distribution (cf. HedGPeth, 1949, 1963; Losina-LosinsKy, 1961).

Further westward too, it is closely related to that of the Maritime Province on the northwestern coast of the Japan Sea; for instance the Possjet Bay and Peter the Great Bay region share a similar relative composition. Nesis (1960) recorded from the former bay Nymphon striatum, Achelia echinata sinensis, A. segmentata, A. aff. laevis, A. gracilipes, Lecythorhynchus hilgendorf, of which 4 species are common on the southeastern coast of Hokkaido. Unique species such as 'Halosoma' derjugini, 'Pycnosomia strongylocentroti' (=-Pigromitus tismanus Calman, after Hedgpeth, 1948), which were originally reported by Losina-Losinsky $(1929,1933,1961)$ from the Maritime Province, have not yet been found from the northern coasts of Japan including Hokkaido.

Callipallene dubiosa HedgPeth (1949) was originally recorded from the shore of Hakodate, southwestern end of Hokkaido, but later refound far southward, i.e. off Amoy, 8-25 fms, Singapore, low tide and Indian coast, 1-5 fms (STock, 1954). Judging from its wide range of distribution pattern, this may not be a boreal species but a tropical species immigrated northerly by the route of the warm Tsushima Current branched from the Kuroshio Main Gurrent in the southwest of Kyushu.

Japan Sea. The same may be said for the co-existence of the northern and southern elements in the northeastern marginal area of the Japan Sea, especially on the southwestern coast of Hokkaido and the Tsugaru Straits; as far as the coastal or offshore Nymphons are concerned, for instance Nymphon japonicum, N. kodanii, N. micropedes, $N$. ortmanni (of the southern elements) and $N$. longitarse, $N$. braschnikowi (probably $N$. striatum, $N$. grossipes too) of the northern elements are known to live together in this restricted area. This area coincides well with the eastern end of the boundary between the subarctic Hokkaido and the temperate Northern Japan Region, based on the distribution of shallow-water cirripeds (UTinomi, 1955b, p. 118, fig. 1) and with the northeastern end of the discontinuity belts of distribution of southern and northern elements of marine animals which was emphatically generalized by NisHI- 
MURA (1965, p. 52, fig. 2).

Although the nearshore and littoral pycnogonid fauna around the Japan Sea coasts has not been fully explored with the exceptions of the Peter the Great Bay, the Possjet Bay area and the coasts of Aomori Prefecture, northern end of Honsyu Island, the offshore fauna was comparatively well explored by several expeditions conducted by Russian (1925-32), United States (Albatross, 1900-06), Danish (Dr. Th. Mortensen , 1914-16) and Japanese (Soyo-maru, 1926-30) workers.

Generally speaking, the area here concerned, i.e. the southeastern marginal area of the Japan Sea or the Japan Sea side of Japan proper, corresponds to the Subtropical Region where is the southern part of the Japan Sea bioclimatically demarcated from the northern part (cf. Nishimura, 1968, p. 112, fig. 46). As the name of the biogeographical region signifies, the pycnogonids occurring there are dominated by the southern subtropical or tropical forms, penetrating through the Korea Straits in lesser degree than along the Pacific coast where the main stream of the warm Kuroshio Current vigorously flows to the northeastward direction.

Putting aside the main deep-water dwellers and endemic species, e.g. Phoxichilidium ungellatum can be taken up in considering the distribution pattern in the Japan Sea. This species is prevalent in all coastal waters around Japan proper, as shown by the Albatross and Soyo-maru records. It extends the distributional range far northward to the south of the Kamtchatka Peninsula of the subarctic region along the Pacific coast, while it reaches only the south of Sado Island on the north along the Tsushima Current in the Japan Sea. Then, among the Callipallenidae, Callipallene dubiosa and Parapallene nierstras $z i$ can be considered as tropical immigrants, the former being recorded from Hakodate facing the Tsugaru Straits and the latter from the east of Tsushima Island in the Korea Straits as the northern limit of their range respectively. It seems likely that these immigrants ever penetrated into the Japan Sea from the southern home regions may be rather eurythermic or euryhaline, insofar as our present knowledge of the coastal pycnogonid fauna (the cirriped fauna as well) of comparable regions is concerned (cf. Nishimura, 1965-69; Utinom, 1970).

Western Kyushu. The offshore pycnogonid fauna of western Kyushu north to the Korea Straits has been rather more elucidated than elsewhere, particularly by the Albatross and Dr. Th. Mortensen's Expeditions. This region, where the Kuroshio is divided into two routes, the northward flowing Tsushima Current and the eastward flowing main warm current, is represented by considerable numbers of Pycnogonida, both endemic and southern tropical, probably richer than that all along the Pacific coasts of Japan proper as far north as the Sagami Bay.

The shallow-water and littoral species have been collected more or less extensively by benthos dredging or shore-collecting. As the bulk of the collections were made by the staff members of the Hama Branch of the Seikai Regional Fisheries Research Laboratory and the Amakusa Marine Biological Laboratory particularly around the Ariake Sound, Chijiwa Bay and Amakusa Islands in recent years, the nearshore 
pycnogonid fauna of this region has been revealed considerably.

As a result, some of the pycnogonids which had been generally believed as true deep-water dwellers are found rather commonly in nearshore waters of western Kyushu, thriving particularly in Chijiwa Bay of about $20-80 \mathrm{~m}$ depths. They are for example:

$\begin{array}{lll}\text { Nymphon japonicum, } & \text { Ascorhynchus auchenicus, } & \text { Colossendeis chitinosa, } \\ \text { Cilunculus armatus, } & \text { As. glabroides, } & \text { C. dofleini. } \\ & \text { As. glaberrimus, } & \text { Pycnogonum tenue. }\end{array}$

Besides, several southern tropical species have been found there for the first time as new additions to the Japanese fauna. They are: Pallenopsis hoeki, Pseudopallene zamboangae, Endeis meridionalis and Achelia nana.

In connection with this, it should be noted that the two curious endemic species, i.e. Heterofragilia amica (offshore) and Nymphonella tapetis (nearshore) which were originally described from western Kyushu are so far unknown elsewhere in Japan.

Seto Inland Sea (Seto Naikai or Setouchi). This well known 'Inland Sea of Japan' is a shallow sea plain, subsided in the Pliocene to the Pleistocene Periods, and now connected with the open sea by the four channels (Kii Channel on the southeast, Bungo Channel on the southwest and Kanmon Channel on the northwest), through which the oceanic warm-water is poured into the main sea area, particularly the surface layers. This sea area, located between Chûgoku (western part of Honsh $\hat{u}$ ), Shikoku and Kyûshû, is thus hydrographically closed in nature and faunistically subtropical, as it is called "Japanese Mediterranean" (Ekman, 1953, p. 25).

The mean depth of the Seto Inland Sea is 20-30 m and deeper basin than $100 \mathrm{~m}$ is confined only to a narrow area of Bungo Channel, $130 \mathrm{~m}$ at the deepest (InABA, 1963, p. 1), and the spring tide range is $3.6 \mathrm{~m}$ in the western part, in contrast to about $1.8-2.0 \mathrm{~m}$ on the Pacific Ocean coasts.

The littoral fauna of this region contains no endemic species but deserves special mention.

The Zostera belt and gravel shores prevailing in the Seto Inland Sea and inner bays elsewhere are dominated by the following small-sized pycnogonids inhabiting between sea-weeds or under stones, or occasionally on benthic animals (e. $g$. seacucumbers, sea-skirts, etc.), not as true commensals. They are:

$\begin{array}{ll}\text { Propallene longiceps, } & \text { Ammothella biunguiculata, } \\ \text { Callipallene emaciata amaxana, } & \text { Lecythorhynchus hilgendorfi, } \\ \text { Anoplodactylus gestiens, } & \text { Achelia echinata sinensis. }\end{array}$

Some of these littoral species are often collected with tow nets as already reported by Oнsнima (1933c). The other species, which are temporarily pelagic in their life cycle (e. g. Achelia alaskensis, Phoxichilidium ungellatum, etc.) may be reckoned as similar examples, and their pelagic habit might be expected to favor them to disperse to a wider range. 


\section{REFERENCES}

(Mainly concerned with the Japanese fauna.)

Arita, K. 1936. Ein überzählinges Bein bei einer Pantopoden-Art (Nymphonella tapetis Ohshima). Annot. Zool. Japon., 15 (4) : 469-479.

1937. Beiträge zur Biologie der Pantopoden. Journ. Dept. Agric., Kyushu Imp. Univ., 5 (6) : 271-288.

Barnard, K.H. 1954. South African Pycnogonida. Ann. S. Afr. Mus., 41 (3): 81-158.

Böнм, R. 1879a. Ueber die Pycnogoniden des Königl. Zoologischen Museums zu Berlin, insbesondere über die von S.M.S. Gazelle mitgebrachten Arten. Monatsber. Königl. Akad. wiss. Berlin, 1879: 170-197, 2 pls.

1879b. Ueber zwei neue von Dr. Hilgendorf in Japan gesammelte Pycnogoniden. Sitzb. Ges. Naturf. Freunde Berlin, 1879 (1): 53-60.

- 1879c. Ueber Pycnogoniden. Ibid., 1879 (9) : 140-142.

Bourdillon, A. 1954a. Les Pycnogonides de Marseille et des environs. Rec. Tr. St. Mar. Éndoume, fasc. 12: 1-160.

- 1954b. Contribution a l'etude des pycnogonides de Tunisie. Sta. Océanogr. de Salammbô, Notes, no. 35: 3-8, pl. 1 .

Bouvier, E.-L. 1923. Pycnogonides. Faune de France, 7: 1-69.

Galman, W.T. 1922. The holotype of Parazetes auchenicus, Slater (Pycnogonida). Ann. Mag. Nat. Hist., ser. 9, 9: 199-203.

- 1923. Pycnogonida of the Indian Museum. Rec. Indian Mus., 25 (3) : 265-299.

- 1938. Pycnogonida. The John Murray Expedition 1933-34, Sci. Reps., 5 (6): 147-166.

Calvez, J. Le 1950. Un Pycnogide nouveau pour la Méditerranée: Nymphonella tapetis Ohshima. Arch. Zool. exp. et gén., 86, Notes et Revue, no. 3: 114-117.

Carpenter, G.H. 1893. Reports on the zoological collections made in Torres Straits by Professor A.C. Haddon 1888-1889. Pycnogonida (Supplement). Sc. Proc. Roy. Dublin Soc., n. ser., 7: 21-27, pl. 2 .

1904. Report on the Pantopoda collected by Professor Herdman, at Ceylon, in 1902. Rep. Ceylon Oyster Fish. pt. 2, Suppl. Reps. no. 13: 181-184, 1 pl.

1907. Pycnogonida. Percy Sladen Trust Exp., vol. 1, no. 7; Trans. Linn. Soc. London, ser. 2, 12 (zool.) : 95-101, pls. 12-13.

Clark, W.C. 1963. Australian Pycnogonida. Rec. Aust. Mus., 26 (1): 1-81.

Cole, Leon J. 1904. Pycnogonida of the west coast of North America. Harriman Alaska Exped., 10: 249-298, pls. XI-XXVI.

Dohrn, A. 1881. Die Pantopoden des Golfes von Neapel und der grenzenden Meeres-Abschnitte. Fauna u. Flora Golfes Neapel, monogr. 3: 1-252, pls. 1-81.

Ekman, S. 1953. Zoogeography of the sea. Sidgwick \& Jackson, London.

Flynn, T. Th. 1928. The Pycnogonida of the marine survey of South Africa. Fish \& Mar. Biol. Survey, Rep. no. 6 (1927-1928), Spec. Rep. no. 1: 1-36.

1929. Pycnogonida from the Queensland coast. Mem. Queens1. Mus., 9 (3): 252-260.

FukuI, T. 1919. [The structure and kinds of Pantopoda.] Rigakukai, 16 (2): 95-99. (In Japanese.)

Guille, A. et J. Soyer 1968. Nouvelle signalisation du genre Nymphonella Ohshima à Banyuls-surMer: Nymphonella lecalvezi n. sp. Vie et Milieu, 18 (2A) : 345-353.

Hedgpeth, Joel W. 1941. A key to the species of the Pycnogonida of the Pacific coast of North America. Trans. San Diego Soc. Nat. Hist., 9 (26): 253-260, pls. 9-11.

1948. The Pycnogonida of the western North Atlantic and the Caribbean. Proc. U.S. Nat. Mus., 97 (3216): 157-342, charts 1-2.

1949. Report on the Pycnogonida collected by the Albatross in Japanese waters in 1900 and 1906. Ibid., 98 (3231): 233-321, chart 1.

1952 (1956). Ricketrs, E.F. and J. Calvin: Between Pacific tides, Revised Edition. Stanford Univ. Press, Stanford, California. 
1954. Class Pycnogonida. In: SMITH, Ralph. I. et al., Intertidal invertebrates of the central California coast: 201-210. Univ. California Univ. Press. Berkeley and Los Angeles.

1963. Pycnogonida of the American Arctic. J. Fish. Res. Bd. Canada, 20 (5): 1315-1348.

Helfer, H. 1938. Einige neue Pantopoden aus der Sammlung des Zoologischen Museums in Berlin.

Sitzber. Ges. Naturf. Freunde Berlin, 1937: 162-185.

Hirton, W.A. 1939. A preliminary list of Pycnogonids from the shores of California. Journ. Entomol. \& Zool., (Pomona Coll.), 31 (2) : 27--35.

1942a. Pantopoda. Pantopoda chiefly from the Pacific. I. -Nymphonidae. Ibid., 34 (1): 3-7.

1942b. Pycnogonids from Allan Hancock Expeditions. Allan Hancock Pacif. Exped., 5 (9):

277-339, pls. 35-48.

-1942c. Pantopoda (continued). II. -Family Callipallenidae. Journ. Entomol. \& Zool. (Pomona

Coll.), 34 (2): 38-41.

- 1942d. Pycnogonids from Hawaii. Occ. Pap. Bishop Mus., 17 (3): 43-55.

1942e. Pycnogonids from the Pacific. Family Tanystyllidae. Journ. Entomol. \& Zool. (Pomona

Coll.), 34 (3): $69-70$.

1942f. Pycnogonids from the Pacific. Family Phoxichilidae Sars 1891. Ibid., 34 (3): 71-74.

1942g. Pycnogonids from the Pacific. Family Ammotheidae. Ibid., 34 (4) : 93-99.

1943a. Pycnogonids from the Pacific. Family Colossendeidae. Ibid., 35 (1) : 2-4.

1943b. Pycnogonids from the Pacific. Family Pycnogonidae and Family Endeidae. Ibid., 35

(2): 19 .

Hoek, P.P.C. 1881. Report on the Pycnogonida dredged by H.M.S. Challenger during the years 1873-76. Rep. Sci. Res. Voyage Challenger 1873-76, Zool., 3 (10): 1-167, pls. 1-21.

1898. On four Pycnogonids, dredged during the cruise of the Challenger; investigated and described after the completion of the report. Tijdschr. Ned. Dierk. Ver., ser. 2, $5(2 / 4): 290-300$, pls. II-III.

IchikawA, S, and M. Yamada 1957. [Catalogue of marine invertebrates near the Osyoro Bay.] 13 pp. (Pantopoda: 10). Sapporo. (In Japanese.)

InABA, A. 1963. Fauna and flora of the Inland Sea of Seto. (Pycnogonida: 205-206) Publ. by the Mukaishima Marine Biological Station. (In Japanese.)

Ives, J.E. 1891. Echinoderms and Arthropods from Japan. Proc. Acad. Nat. Sci. Philadelphia, 43: 210-223, pls. VII-XII.

Kishida, K. 1927. Pantopoda. In: Nippon Dôbutsu Zukan [Figuraro de Japanaj Bestoj]: 989-990, figs. 1905-1908. Hokuryûkwan \& Co., Tokyo. (In Japanese.)

Loman, J.C.C. 1908. Die Pantopoden der Siboga Expedition. Siboga Expeditie, monogr. 40: 1-88, pls. 1-15.

1911. Japanische Podosomata. Abh. math. -phys. Kl. K. Bayer. Akad. Wiss. II. Suppl. -Bd. 4 Abhandl.: 1-18, pls. 1-2.

Losina-Losinsky, L.K. 1929. Ueber einige neue Formen der Pantopoda. Zool. Jahrb., Abt. Syst., 57 (5): 537-554.

- 1933. Pantopoda bostochynkh morei S.S.S.R. [Die Pantopoden der östelichen Meere der USSR]. Leningrad Inst. Issledovanija Morei SSSR, 17: 43-80. (In Russian and German.)

- 1961. Mhogokolenchatye (Pantopoda) dalnjewostotschynch morjei SSSR [Pantopoda of the far eastern seas of the USSR.] Issledovania Palnjewostotschnych Morjei SSSR, 7:47-117. (In Russian.)

and E.P. Turpaeva 1958. Rod Colossendeis (Pantopoda) severnoj uasti tikhologo okeana [The genus Colossendeis (Pantopoda) in the northern part of the Pacific Ocean.] Bjull. Moscov Obschestva Ispyteljei Prirody, 63 (1) : 23-33. (In Russian, with English summary.)

Lou, Ting-Heng 1936a. Sur deux nouvelles variétés de pycnogonides recueillies à Tsing-Tao, dans la Baie de Kiao-chow, Chine. Gontr. Inst. Zool. Nat. Acad. Peiping, 3 (1): 1-34, pls. I-IV.

- 1936b. Notes sur Lecythorhynchus hilgendorf Böhm (Pycnogonida). Ibid., 3 (5): 133-163, pls. XIXIII. 
Marcus, E. 1940. Os Pantopoda brasileiros e os demais subamericanos. Bol. Fac. Fil., Ciênc. Letr. Univ. S. Paulo, 19 (Zoologia no. 4): 3-179, pls. 1-17.

Miers, E.J. 1884. Pycnogonida. Rep. Zool. Coll. Voyage H.M.S. 'Alert' 1881-2, London: 323-326, pl. 35.

Nesis, K.N. 1967. Pantopoda of the Possjet Bay and southern Sakhalin collected by the underwater hydrobiological expedition of the Zoological Institute, Academy of Sciences, USSR. Issledovanija fauny Morei, V (XIII) : 248-251 (In Russian.)

Nishimura, S. 1964. Origin of the Japan Sea as viewed from the evolution and distribution of marine fauna. Parts I and II. Chikyûkagaku, 73: 18-27; 75: 29-46. (In Japanese, with English summary.) - 1965-69: The zoogeographical aspects of the Japan Sea. Parts I-V. Publ. Seto Mar. Biol. Lab., 13: 35-79, 81-101, 365-384; 15: 329-352; 17: 67-142.

Ohshima, H. 1927a. Nymphonella tapetis, n. g., n. sp. a pycnogon parasitic in a bivalve. Annot. Zool. Japon., 11 (3): 257-263.

1927b. Notes on some pycnogons living semiparasitic on holothurians. Proc. Imp. Acad., $3(9): 610-613$.

- 1927c. Piknogono parazite vivanta en Bivalvo. Bull. Sci., Fak. Agr. Kyushu Imp. Univ., 2 (5) : 366-379, pls. 5-6. (In Japanese, with Esperanto summary.)

- 1927d. Piknogoj alkrocigantaj al Holoturioj. Ibid., 2 (5): 380-388. (In Japanese, with Esperanto summary.)

1933a. The adult of the bivalve-infesting Pycnogonid, Nymphonella tapetis Ohshima. Annot.

Zool. Japon., 14 (1): 53-60.

1933b. Young pycnogonids found parasitic on nudibranchs. Ibid., 14 (1): 61-66.

1933c. Pycnogonids taken with a tow-net. Ibid., 14 (2): 211-220.

1933d. Pycnogonids of the North Kuriles. Bull. Biogeogr. Soc. Japan, 4 (2): 143-150. (In Japanese, with English résumé.)

- 1933e. [Four articles on Pycnogonida] (Lecture abstract) Zool. Mag., 45 (532/533): 94-97.

(In Japanese.)

1935a. [On pycnogonids from Okinawa Region.] Ibid., 47 (557): 137-139. (In Japanese.)

1935b. A further note on Nymphonella tapetis: the egg-carrying mature male (Eurycydidae,

Pantopoda). Annot. Zool. Japon., 15 (1): 95-102.

1936. A list of Pycnogonida recorded from Japanese and adjacent waters. Zool. Mag., 48

(8-10): 861-869. (In Japanese, with English résumé.)

1937. The life-history of "Nymphonella tapetis" Ohshima ("Pantopoda, Eurycydidae").

G.R. XIIe Congres Intern. de Zoologie-Lisbonne, 1935: 1616-1626, pl. LXXX.

1938. Nymphonellidae, a new family of Pantopoda. Annot. Zool. Japon., 17 (3-4) : 229-233.

1939a. La vivhstorio de Piknogono (Nymphonella tapetis) vivanta parasite en Bivalvo. Volumen

Jubilare pro Prof. Sadao Yoshida: 415-434. (In Japanese.)

-- 1942a. Six-legged pantopod, an extraordinary case of hypomery Arthropods. Proc. Imp.

Acad. Tokyo, 18 (5) : 257-262.

- 1942b. A remarkable case of malformed legs in a pantopod, Nymphonella tapetis. Ibid., 18

(5) : 520-523.

1943a. [A curious example of abnormal legs in a pantopod, Nymphonella tapetis.] Zool. Mag.,

55 (2): 91. (In Japanese.)

- 1943b. Du maloftaj kazoj de nenormaleco en Pantopodoj. Bull. Sci., Fac. Agr., Kyushu

Imp. Univ., 10 (4): 371-382. (In Japanese, with Esperanto résumé.)

—_ and K. Kishida 1947. Pantopoda. In: Nippon Dôbutsu Zukan [Illustrated Encyclopedia of the Fauna of Japan (exclusive of insects)], Revised edition : 1005-1010, figs. 2855-2866. Hokuryûkan, Tokyo. (In Japanese.)

OKuDA, Sh. 1934. On a tubicolous polychaete living in commensal with a pycnogonid. Annot. Zool. Japan., 14 (4) : 437-439.

- 1940. Metamorphosis of a pycnogonid parasitic in a hydromedusa. J. Fac. Sci., Hokkaido Imp. Univ., ser. VI, Zool., 7 (2): 73-86. 
Ortmann, A. 1890. Bericht über die von Herrn Dr. Döderlein in Japan gesammelten Pycnogoniden. Zool. Jahrb., Abt. Syst., 5 (1): 157-168, pl. XXIV.

SANDo, H. 1964. Faunal list of the Zostera marina region at Kugurizaka coastal waters, Aomori Bay. Bull. Mar. Biol. Sta. Asamushi, 12 (1): 27-35 (Pycnogonida: 30)

Sanmkewitsan, W. 1929. Pantopoda. Faune de l'URSS et des pay limitrophes. Leningrad. Livr. 1: I-CXV, 1-224, pls. 1-4.

1930. Ditto. Livr. 2: 225-555, pls. 5-10.

Shrshido, I. 1899. [Japanese Pantopoda.] Zool. Mag., 11 (128): 195-200. (In Japanese.)

SlATER, H.H. 1879. On a new genus of pycnogon and a variety of Pycnogonum littorale from Japan. Ann. Mag. Nat. Hist., ser. 5, 3 (16) : 281-283.

Stock, Jan H. 1951. Pantopoda. Res. Sci. Crois Navire: École Belge 'Mercator', 5; Mém. Inst. Roy. Sci. Nat. Belg., sér. 2, fasc. 43: 1-23.

1952a. Revision of the European representatives of the genus Callipallene Flynn, 1929. Beufortia $1(13): 1-14$.

1953a. Re-description of some of Helfer's pycnogonid type-specimens. Ibid., 4 (35): 33-45. 1953b. Biological results of the Snellius Expedition. XVII. Contribution to the knowledge of the Pycnogonid fauna of the East Indian Archipelago. Temminckia, 9: 276-313.

-.. 1954. Papers from Dr. Th. Mortensen's Pacific Expedition 1914-1916. LXXVII. Pycnogonida from Indo-West-Pacific, Australian, and New Zealand waters. Vidensk. Medd. fra Dansk naturh. Foren., 116: 1-168.

1955. Ditto. LXXVIII. Pycnogonida from the West Indies, central America, and the Pacific coast of North America. Ibid., 117: 209-266.

- 1956. Tropical and subtropical Pycnogonida, chiefly from South Africa. Ibid., 118: 71-113 (with detailed bibliography of Pycnogonida up to date).

- 1957a. Pantopoden aus dem Zoologischen Museum Hamburg. 2 Teil. Mitt. Hamburg. Zool. Mus. Inst., 55: 81-106.

1957b. The pycnogonid family Austrodecidae. Beaufortia, 6 (68): 1-81.

1959. On some South African Pycnogonida of the University of Cape Town ecological survey. Trans. Roy. Soc. S. Africa, 35 (5): 549-567.

1962. Second list of Pycnogonida of the University of Cape Town ecological survey. Ibid., 36 (4) : 273-286.

- 1965. Pycnogonida from the southwestern Indian Ocean, Beaufortia, 13 (151): 13-33.

1968a. Pycnogonida collected by the Galathea and Anton Bruun in the Indian and Pacific Oceans. Vidensk. Meddr. Dansk naturh. Foren., 131 : 7-65.

- 1968b. Pycnogonides. Faune marine des Pyrénées-Orientales, Fasc. 6: 1-38. Masson, Paris.

Suzuki, Sh. 1963. Fauna of the coast of Shônai and the adjacent sea. 43 pp. (Pycnogonida: 12) Publ. by the author, Yamagata. (In Japanese.)

Uchida, H., Konno, K. and Sh. Chiba 1970. A preliminary list of marine animals found in the vicinity of the Fukaura Marine Biological Laboratory, Part 2. Rep. Fukaura Mar. Biol. Lab., no. 2: 7-29 (Pycnogonida: 10). (In Japanese.)

Utrnomi, H. 1950. [Pycnogonida from the Kii Province (Records of collections by dredging from off Minabe, Kii Prov., Rep. 1)]. Nanki Seibutsu, 1 (3): 127-132. (In Japanese, mimeographed.) 1951. On some pycnogonids from the sea around Kii Peninsula. Publ. Seto Mar. Biol. Lab., 1 (4) : 159-168.

- 1954. The fauna of Akkeshi Bay. XIX. Littoral Pycnogonida. Publ. Akkeshi Mar. Biol. Sta., 3: $1-28$, pl. 1 .

- 1955a. Report on the Pycnogonida collected by the Sôyô-maru Expedition made on the continental shelf bordering.Japan during the years 1926-1930. Publ. Seto Mar. Biol. Lab., 5(1):1-42.

- 1955b. Studies on the Cirripedia of Japan. II. Geographical distribution. Bull. Biogeogr. Soc. Japan, 16-19: 113-123. (In Japanese, with English résumé.)

- 1959. Pycnogonida of Sagami Bay. Publ. Seto Mar. Biol. Lab., 7 (2): 197-222.

1962. Pycnogonida of Sagami Bay-Supplement. Ibid., 10 (1): 91-104. 
- 1965. Pycogonida. In: Shin Nippon Dobutsu Zukan [New Illustrated Encyclopedia of the Fauna of Japan], Vol. 2: 333-338, figs. A-D, 12-31. Hokuryû-kan, Tokyo. (In Japanese.)

- 1966. Subphylum Pycnogonida. Dôbutsu Keitôbunruigaku, 7 (Mid B): 1-14. Nakayamashoten, Tokyo. (In Japanese.)

- 1970. Studies on the Cirripedian fauna of Japan. IX. Distributional survey of thoracic cirripeds in the southwestern part of the Japan Sea. Publ. Seto Mar. Biol. Lab., 17 (5) : 339-372, pl. XVIII.

Williams, G. 1939. Pycnogonida of western Australia. Contr. fauna Rottnest Island 11. Journ. Roy. Soc. western Austr., 25 (1938-1939) : 33-39.

1941. A revision of the genus Anoplodactylus, together with a new species from Qucensland. Mem. Queensl. Mus., 12 (1): 33-39.

Wilson, E.B. 1878. Descriptions of two new genera of Pycnogonida. Amer. Journ. Sci. \& Arts, ser. 3 , 15: 200-203. 